U.S. Army Coast.Eug. Rer Er. Tech. Rep. CERC-88-16
NOr. 1988

TECHNICAL REPORT CERC-88-16

\title{
SIDE-SCAN SONAR APPLICATIONS FOR EVALUATING COASTAL STRUCTURES
}

by

James E. Clausner, Joan Pope

Coastal Engineering Research Center

DEPARTMENT OF THE ARMY

Waterways Experiment Station, Corps of Engineers

P.O Box 631, Vicksburg, Mississippi 39181-0631
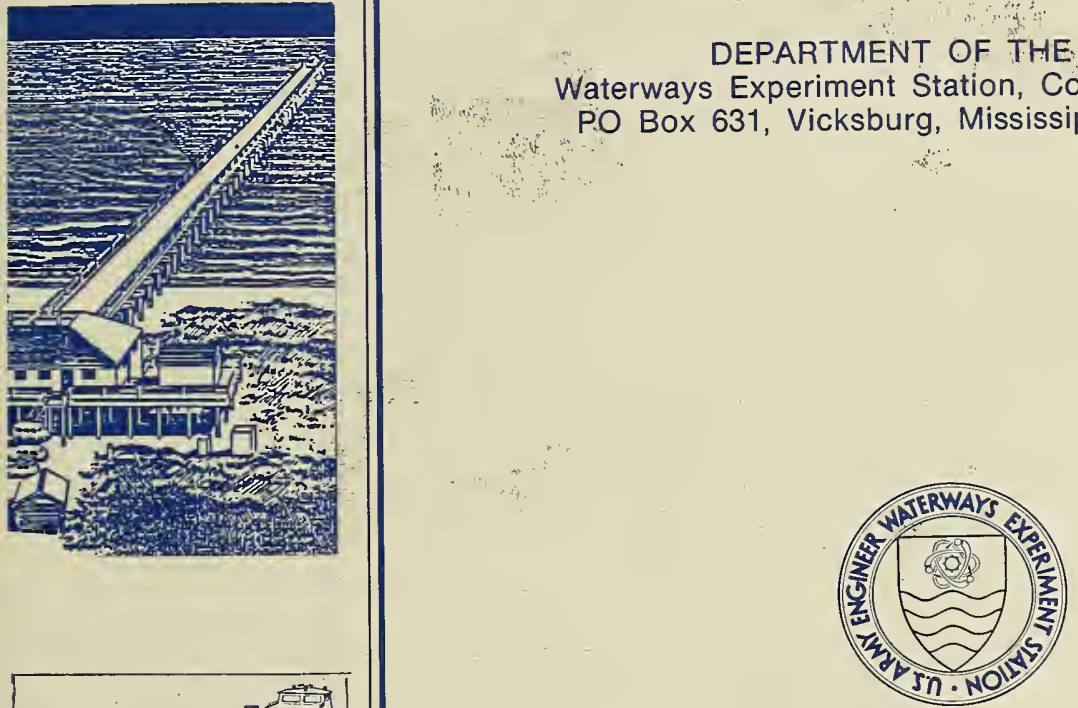

November 1988

Final Report

Approved For Public Release; Distribution Unlimited

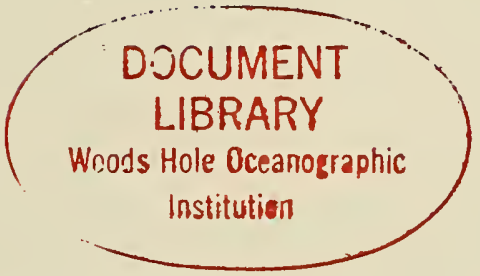

Prepared for DEPARTMENT OF THE ARMY

US Army Corps of Engineers

Washington, DC 20314-1000

Under Work Unit 31232 
Destroy this report when no longer needed. Do not return it to the originator.

The findings in this report are not to be construed as an official Department of the Army position unless so designated by other authorized documents.

The contents of this report are not to be used for advertising, publication, or promotional purposes. Citation of trade names does not constitute an official endorsement or approval of the use of such commercial products. 


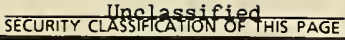

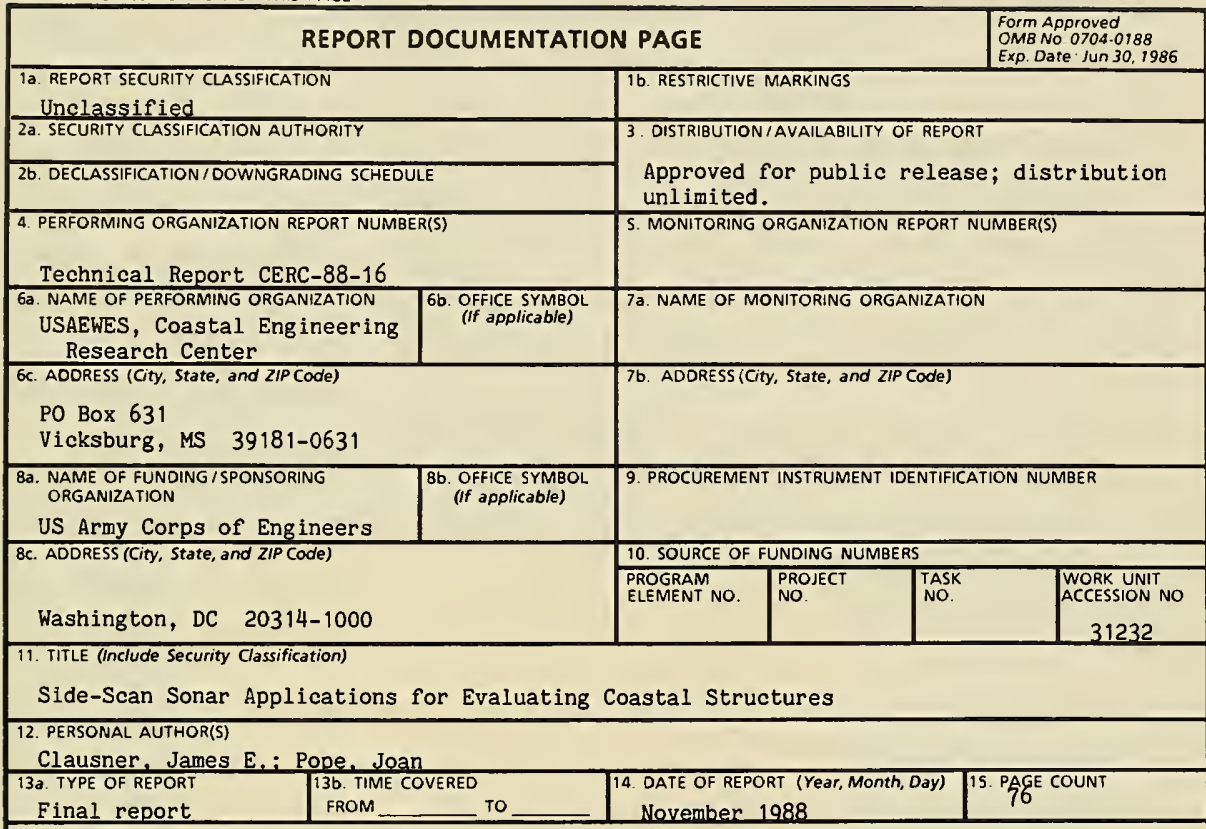

16. SUPPLEMENTARY NOTATION

Available from National Technical Information Service, 5285 Port Royal Road, Springfield, VA 22161.

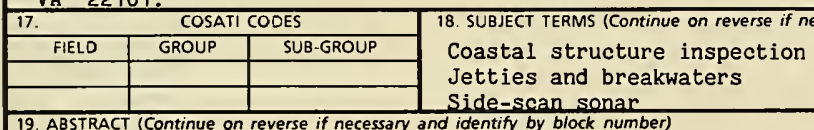

Applications of side-scan sonar for inspecting coastal structures were evaluated. Results were based on 6 years of structure inspections, including structures on the Atlant1c, Pacific, Gulf, and Great Lakes coasts of the United States. Most of the structures inspected were jetties and breakwaters; however, applications for vertical wall structures and dredged materlal disposal sites are presented. Applications discussed include reconnaissance, inspection, and monitoring. Side-scan sonar is most useful as a reconnaissance and inspection tool, allowing long sections of coastal structures to be viewed quickly, at relatively low cost. Operational and interpretation techniques are discussed. Other supplementary tools and techniques, divers, ROV's, and sediment samples are often needed to verify questionable side-scan images. Presently, only qualitative monitoring, such as toe fallures and slope changes, is possible using side-scan sonar.

\begin{tabular}{|c|c|c|c|}
\hline $\begin{array}{l}\text { 20. DISTRIBUTION/AVAILABILITY OF ABSTRACT } \\
\square \text { UNCLASSIFIED/UNLIMITED } \square \text { SAME AS RPT }\end{array}$ & $\square$ DTIC USERS & 21. ABSTRACT SECURITY CLASSIFICAT & TION \\
\hline 22a. NAME OF RESPONSIBLE INDIVIDUAL & & 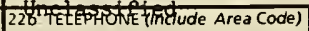 & 22C. OFFICE SYMBOL \\
\hline
\end{tabular}




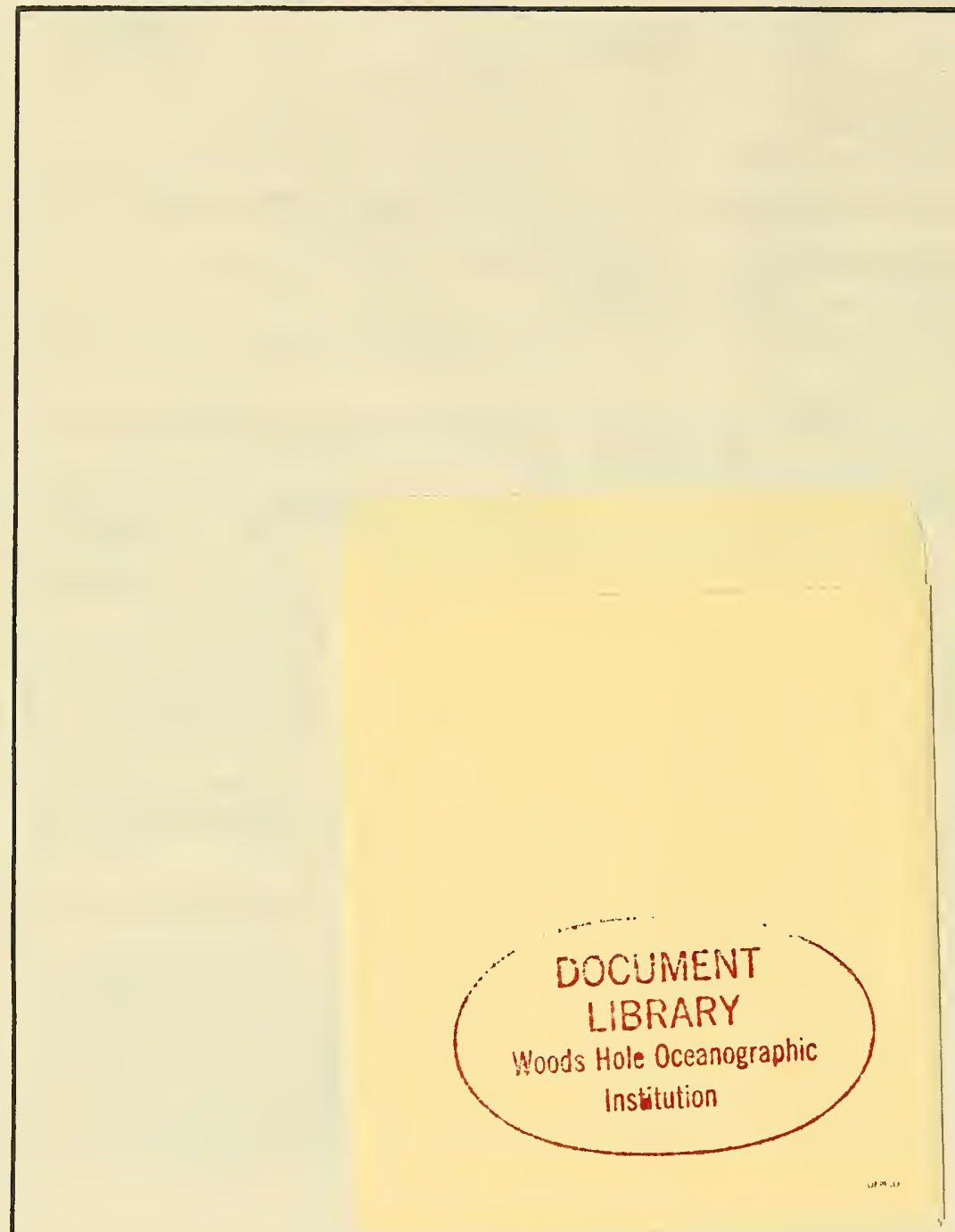


The study summarized in this report was authorized by the US Army Corps of Engineers (USACE) and performed as part of Civil Works Research and Development Work Unit 31232, "Evaluation of Navigation and Shore Protection Structures". Funds were provided through the Coastal Structures Evaluation and Design Program administered by the Coastal Structures and Evaluation Branch (CD-S), Engineering Development Division (CD), of the Coastal Engineering Research Center (CERC) at the US Army Engineer Waterways Experiment Station (WES). Messrs. John H. Lockhart, Jr., John G. Housley, James E. Crews, and Charles W. Hummer were USACE Technical Monitors. Dr. C. Linwood Vincent is CERC Program Manager.

This report was prepared by Mr. James E. Clausner, CD-SE, CERC, and Ms. Joan Pope, Chief, CD S. Dr. Clifford L. Truitt, CD SE, was Principal Investigator (PI) of the work unit. Work was performed under direct supervision of $\mathrm{Mr}$. Thomas W. Richardson, Chief, $\mathrm{CD}$; and under general supervision of Mr. Charles C. Calhoun, Jr., Assistant Chief, and Dr. James R. Houston, Chief, CERC.

A large portion of this report is based on field work conducted at Cleveland Harbor, Ohio. Work was funded by the Monitoring of Completed Coastal Projects (MCCP) Program, a part of the Operations and Maintenance Program of USACE. Mr. J. Michael Hemsley, of the Prototype Measurements and Analysis Branch ( $C D-P), C D$, was the PI for the MCCP Program. He provided valuable guidance for much of the early side-scan sonar work under the MCCP Program and was responsible for including side-scan sonar applications in other projects. The authors wish to acknowledge the following other members of CD-P who provided information and example records on several projects: Mr. Andrew Morang - Calumet Harbor, Illinois, and Burns Harbor, Indiana; Mr. William M. Kucharski - Crescent City, California; and Mr. David D. McGehee - East Pass Inlet, Florida. Messrs. Darryl D. Bishop and Perry L. Reed, CD-S, provided drafting support for many of the figures, and Ms. Shirley A. J. Hanshaw, Information Technology Laboratory, WES, edited this report.

The authors wish also to acknowledge the support and cooperation provided by several Corps coastal districts during this study. Their individual contributions are noted in the report. 
COL Dwayne G. Lee, EN, was Commander and Director of WES during the preparation and publication of this report, and Dr. Robert W. Whalin was Technical Director. 
PREFACE

CONVERSION FACTORS, NON-SI TO SI (METRIC) UNITS OE MEASUREMENT........ 4

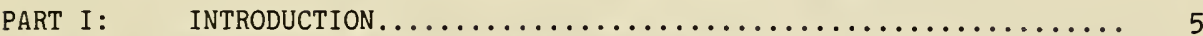

PART II : BACKGROUND AND PRINCIPLES OF OPERATION.............. 7

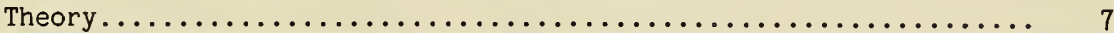

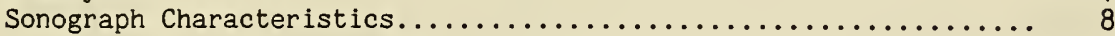

PART III: CERC FIELD EXPERIENCE ......................... 15

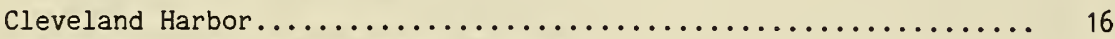

Manasquan Inlet, New Jersey, Jetties................... 25

Ocean City Inlet, Maryland, South Jetty................. 28

Burns Harbor, Indiana, and Calumet Harbor, Illinois........... 30

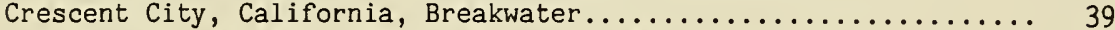

St. Lucie Inlet, Florida, San Bypassing Study.............. 43

East Pass, Florida, Jetties....................... 48

PART IV: OTHER APPLICATIONS OF SIDE-SCAN SONAR INSPECTIONS OF COASTAL RELATED STRUCTURES..................... 51

Vertical Wall Harbor Structures....................... 51

Dredged Material Disposal Sites...................... 53

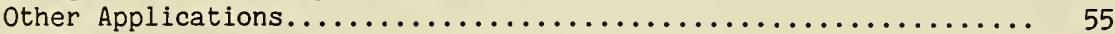

PART V: OPERATING PARAMETERS...................... 57

Vessel Requirements............................... 60

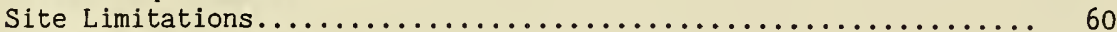

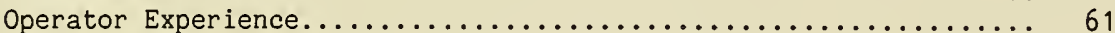

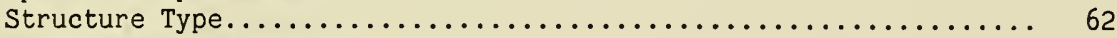

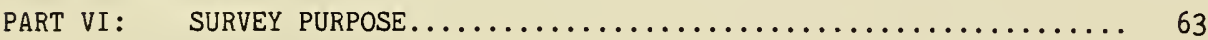

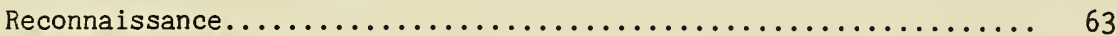

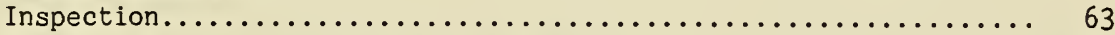

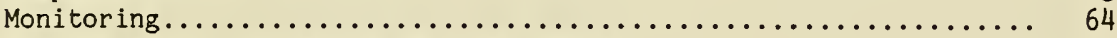

Techniques for Surveying Vertical Walls................. 66

PART VII: $\quad$ APPLICATIONS $\ldots \ldots \ldots \ldots \ldots \ldots \ldots \ldots \ldots \ldots \ldots \ldots \ldots \ldots \ldots \ldots \ldots$

PART VIII: CONCLUSION ................................ 69

REFERENCES.................................... 71 
Non-SI units of measurement used in this report can be converted to SI (metric) units as follows:

Multiply

feet

inches

miles (US statute)

pounds (force)

tons

knots
By

0.3048

2.54

1.609347

4.448222

8.89644

0.514444
To Obtain

metres

centimetres

kilometres

newtons

kilonewtons

metres per second 


\section{PART I: INTRODUCTION}

1. Side-scan sonar is a commercially available acoustical tool for remotely acquiring a qualitative image of submerged objects, including the bottom. The resultant image or sonograph provides a strip map of the area on either side of the towing vessel. The image characteristics, ease of interpretation, and efficiency of operation result in side-scan sonar being an effective tool for planning, designing, constructing, and monitoring coastal works. Side-scan sonar can be used to document an extensive area of structure where water turbidity, currents, or other conditions preclude the use of an optical-based system or diver inspection.

2. Most documented experience with side-scan sonar is in locating debris and obstructions to navigation, finding lost objects, or for mapping and interpreting geological conditions. Williams (1982) describes the use of side-scan sonar for geologic mapping. Side-scan sonar has also proven to be a valuable tool in coastal and nearshore exploration for mapping sources of potential beach nourishment material (Prins 1980). Some monitoring of locks and dams has also been conducted.

3. This report is not a substitute for an operator's manual. A report being prepared under the Repair, Evaluation, Maintenance, and Rehabilitation (REMR) Program (Kurcharski and Clausner, in preparation) provides details on the operation of side-scan sonar in the coastal zone. Rather, this report describes the capabilities of the tool and provides examples of types of coastal structures and particular features that have been imaged using sidescan sonar. It also discusses the effective use of side-scan sonar in documenting coastal construction practices, making qualitative structure condition assessments, and documenting sediment movement patterns around structures. Side-scan sonar techniques have not yet proved to be capable of providing information needed to provide specific design guidance. For example, a side-scan sonar image can show that armoring material has been displaced from the face of a structure and is now lying on or beyond the toe. However, a side-scan sonar image by itself cannot be used to determine what caused the armor to move or give an accurate estimate of the percentage of armor displaced but still remaining on the face. 
4. This report begins with basic information on side-scan sonar, including a brief description of its operation and sonograph interpretation. It then discusses the use of side-scan sonar to document features of coastal structures during CERC field work conducted at various sites. In addition, a review of side-scan sonar inspections of coastal related structures is presented. Discussions on operating parameters and the potential purposes of side-scan sonar surveys follow. The report concludes with a summary of potential applications of side-scan sonar for inspecting coastal structures. 
5. Side-scan sonar evolved from the echo sounding depth finders developed during World War II. In the early 1960's, the first commercial side-scan sonars were used to map the sea bottom and search for submerged objects (Flemming 1976). Although these two functions remain the primary operating areas for side-scan sonar, recent electronic advances and an increased awareness of the capabilities of side-scan sonar have led to its use as a valuable inspection tool for coastal structures.

\section{Theory}

6. In side-scan sonar systems, acoustical energy is projected laterally from a pair of transducers mounted in a towed cylindrical body or "towfish." Each horizontal beam of energy is from 0.2 to $1.5 \mathrm{deg}$ wide (Figure 1). Vertically, the main lobe of the beams covers an angle of approximately 40 deg and is usually aimed $10 \mathrm{deg}$ below the horizontal. Energy in the vertical side

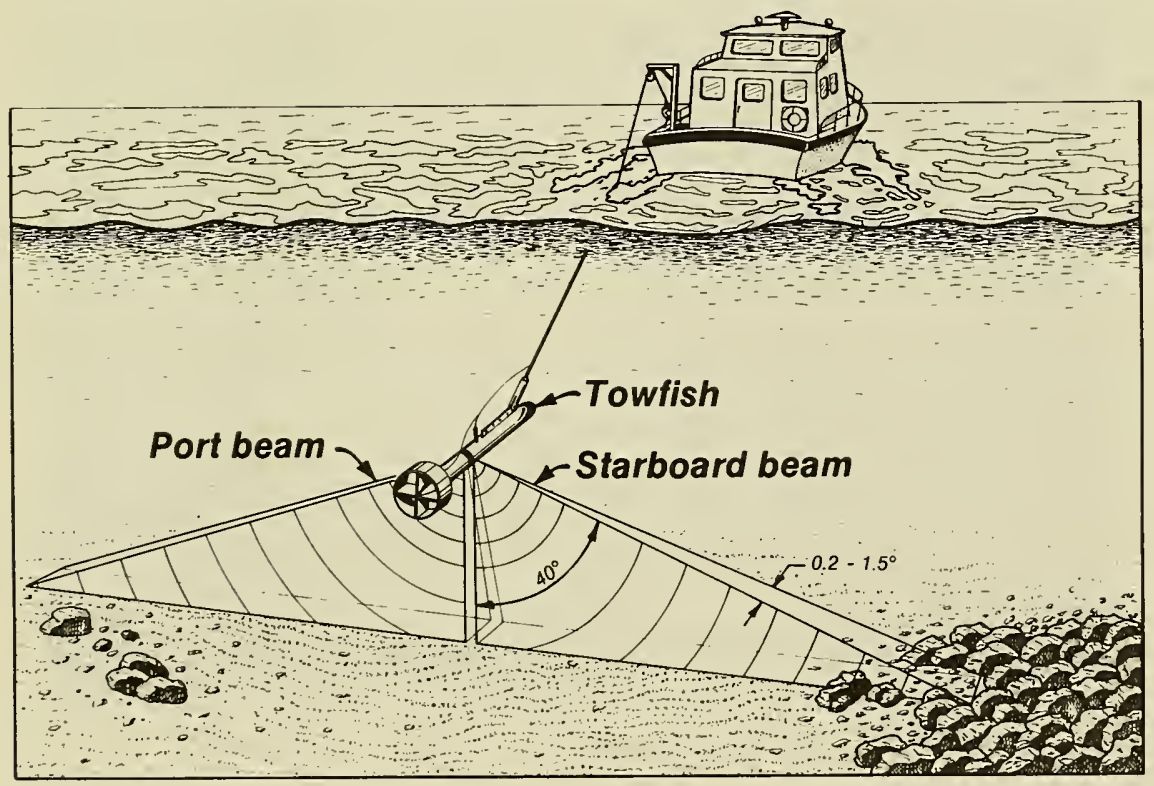

Figure 1. Side-scan sonar in operation 
lobes of the beam (not shown in the simplified Figure 1) allows the towfish to "see" a continuous 180-deg zone, up to the surface and down to the bottom directly below the towfish. However, geometric distortions in the printed record compress the area just below the fish, and lack of energy in the side lobes does not produce an accurate image of the surface.

7. Electrical energy, supplied through the electromechanical tow cable, is applied to the piezoelectric transducers in the towfish. This energy causes them to vibrate, creating sound waves which travel through the water. Sound is reflected from the seabed or structure, received by the same transducers, transmitted back up the tow cable to the recorder, and printed on continuous chart paper (Figure 2). The recorder provides controls to adjust the range, paper speed, printing intensity, and signal gain.

8. Side-scan sonar transducers typically vibrate at preselected frequencies from 50 to $500 \mathrm{kHz}$. Most of the popular commercial units operate at frequencies between 100 and $500 \mathrm{kHz}$. The $100-\mathrm{kHz}$ frequency provides greater range, up to $400 \mathrm{~m}$ on each channel and is most often used for sea bottom mapping and locating objects. A frequency of $500 \mathrm{kHz}$ gives a shorter range, up to $100 \mathrm{~m}$ per beam (also known as a channel), but provides greater resolution and is recommended for detailed inspection of coastal structures under most circumstances.

\section{$\underline{\text { Sonograph Characteristics }}$}

9. Properly interpreting the continuous side-scan sonar image record, commonly known as a sonograph, is often difficult without an understanding of the principles of operation, conditions at the survey site, and the area being viewed. The examples presented in this report will provide a basic understanding of the techniques of interpreting side-scan sonar image records. However, the only way to become proficient is through experience. Klein Associates, Inc. (1985), and Flemming et al. (1982) provide additional information on interpreting side-scan sonar images.

10. The continuous paper image of the bottom or structure produced by the recorder is remotely similar to low level oblique aerial photographs. However, the physics of sound transmission in water is sufficiently different from light transmission in air to produce different image characteristics. Training in the physics of side-scan sonar and in perceiving the distorting 

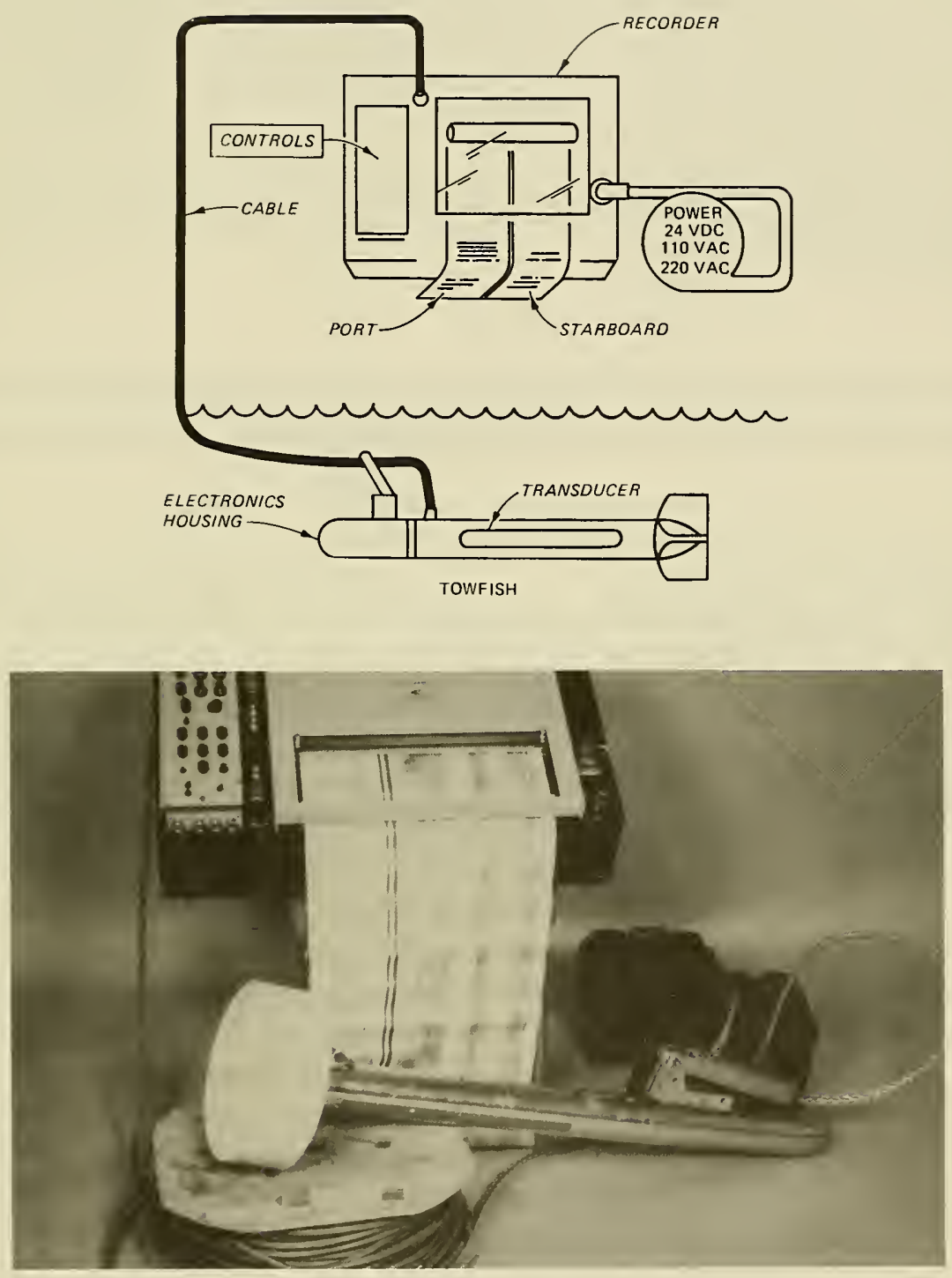

Figure 2. Typical side-scan sonar components (after Klein 1985) 
effects of such on the oblique vantage point is needed to correctly interpret the images. A reasonable description of the side-scan sonar beam is arrived at by comparison to the light areas and shadows formed by an obliquely held flashlight in a darkened room. Figure 3 shows the geometry of side-scan sonar during normal operation.

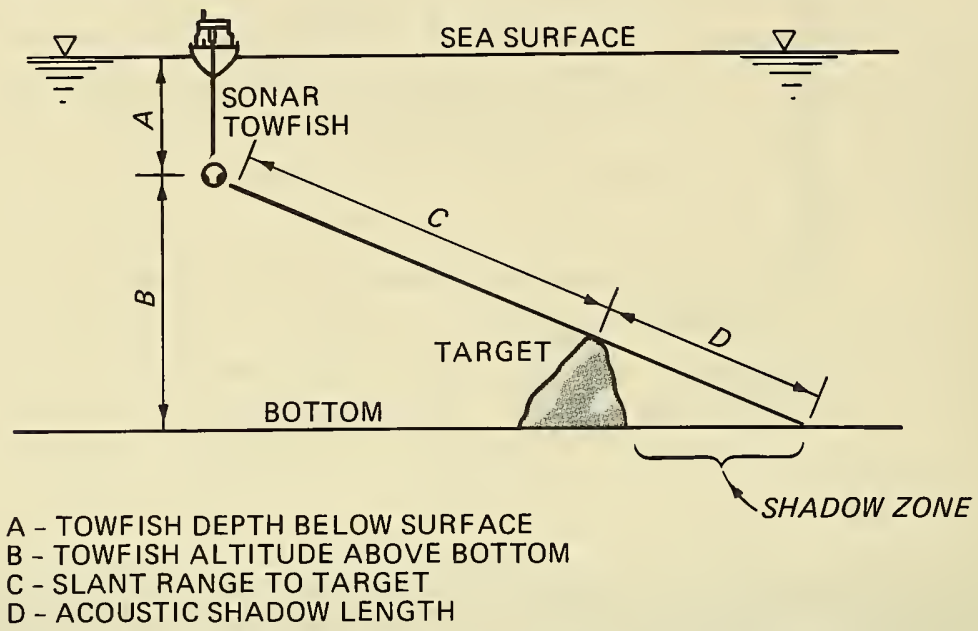

Figure 3. Side-scan sonar geometry (after Klein 1985)

11. A sonograph usually contains two channels of sonar information representing the bottom to the right and left of the towfish. Two dark parallel lines, representing the initial acoustical pulse, run just right and left of the center of the sonograph (Figure 4). The track of the boat and towfish are along these center lines (line A). The surface return (line B) is often the next line closest to the center line (line A). Line $C$, the initial bottom return, is recognizable as the start of the darker tone. Total water depth can be calculated by adding the distances on the sonograph of the output pulse to the surface ( $A$ to $B$ ) and the output pulse to the bottom ( $A$ to $C$ ). Scale lines (D) are at slant range increments of $15 \mathrm{~m}$ (50 ft). As the recorder range settings change (25 to $200 \mathrm{~m}$ per channel on most units), so does the spacing on paper of the range lines since they are always $15 \mathrm{~m}$ ( $50 \mathrm{ft}$ ) apart.

12. The dark line perpendicular to the line of travel (line E) is an event mark created by the operator for later reference. Event marks are 


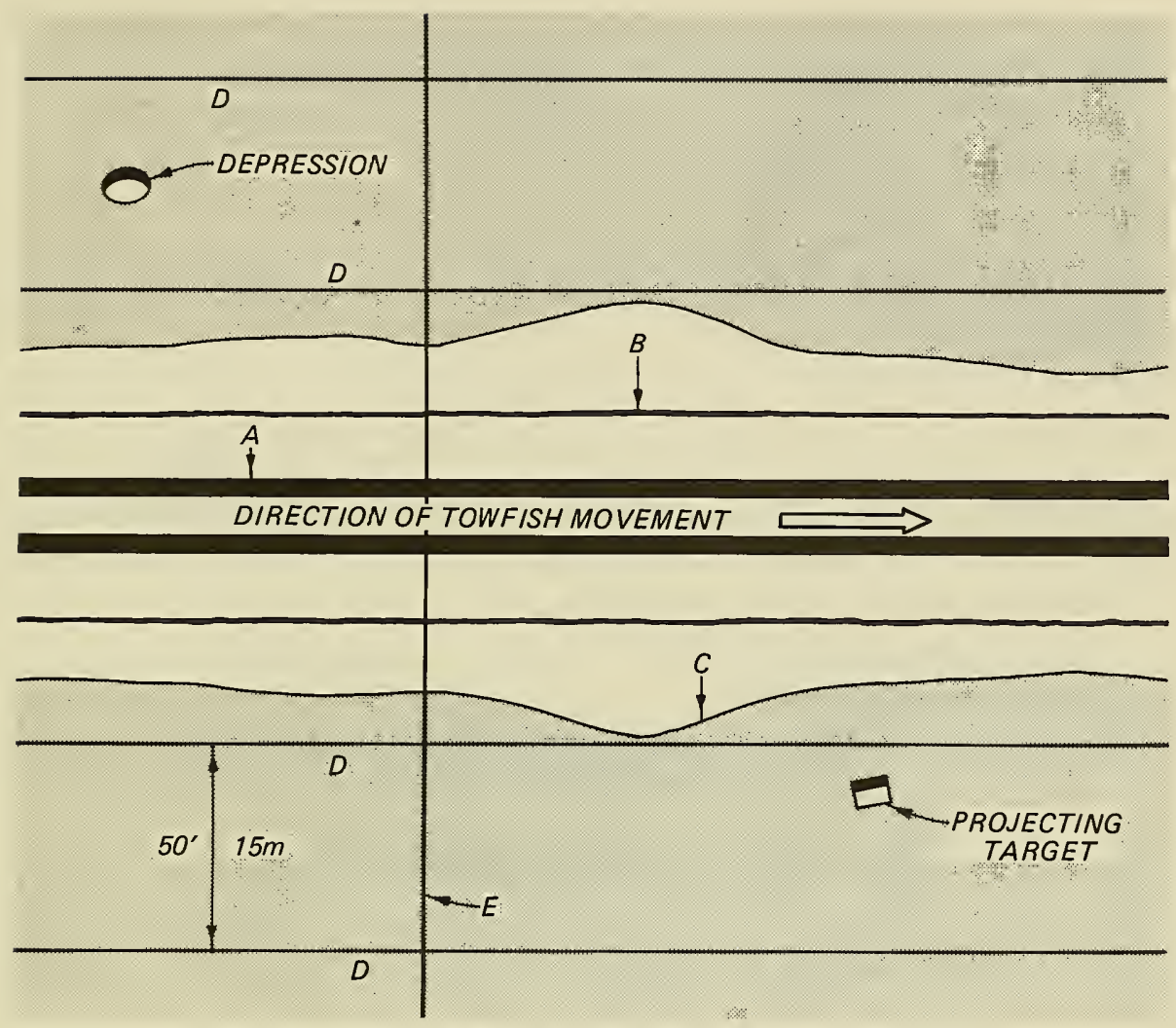

Figure 4. Sample side-scan sonar record (sonograph)

usually used for highlighting an interesting feature or for referencing position. The distance of a target perpendicular to the line of travel can be calculated once the height of the towfish above the bottom is known (Figure 5) by simple trigonometry (i.e., the Pythogorean theorem). The height of a target can be calculated using similar triangles (Figure 6). Several brands of side-scan sonar systems have microprocessor functions available (either built into the recorder or as an accessory component) which will adjust the towfish signal to print a sonograph corrected for slant range. More recent electronic advances allow incorporating vessel speed and/or positioning stations into the data processing, allowing printing of a sonograph with true bottom distances in both directions (Mazel 1984).

13. The sonograph image is of varying shades with each shade a function 


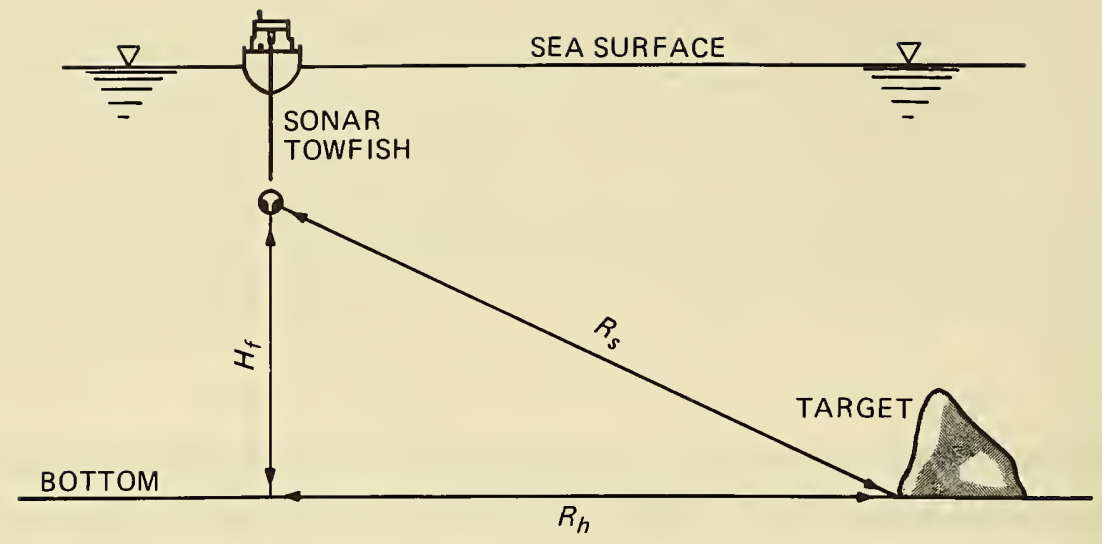

$H_{f}$ - TOWFISH HEIGHT ABOVE BOTTOM

$R_{s}$ - SLANT RANGE TO TARGET

$R_{h}$ - HORIZONTAL RANGE

$$
R_{h}=\sqrt{R_{s}^{2}-H_{f}^{2}}
$$

Figure 5. Calculation of slant range (after Klein 1985)

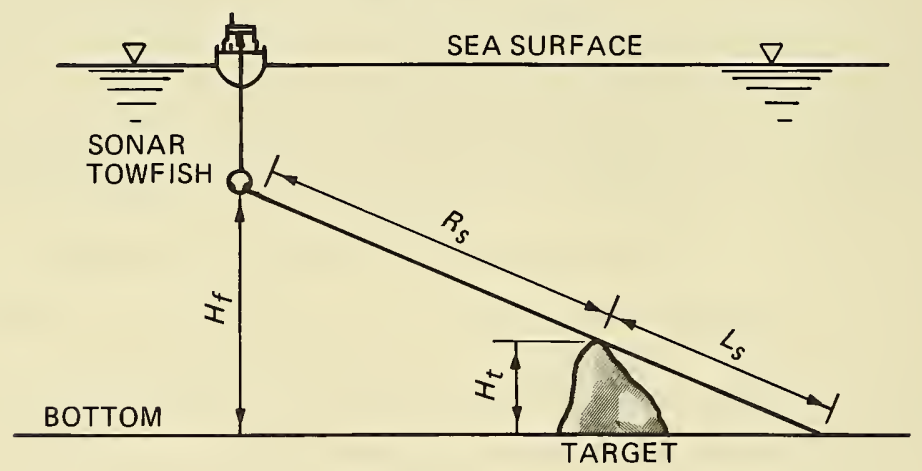

$$
\begin{aligned}
& H_{t}-\text { TARGET HEIGHT } \\
& L_{s} \text { - ACOUSTIC SHADOW LENGTH } \\
& H_{f}-\text { TOWFISH HEIGHT ABOVE BOTTOM } \\
& R_{S}-\text { SLANT RANGE TO TARGET } \\
& R_{S}+L_{s}-\text { SLANT RANGE TO END OF SHADOW } \\
& \text { Figure } 6 . \quad \begin{array}{l}
\text { Calculation of target height } \\
\text { (after Klein 1985) }
\end{array}
\end{aligned}
$$


of the intensity of the returning acoustical pulse. The stronger the returning pulse the darker the image. A number of factors affect the intensity of the returning signal, including acoustic reflectivity of the target, slope of the target face, contrast between the target and surrounding material, and the number of reflecting surfaces.

Target material and orientation influences

14. The acoustic reflectivity of the target is a function of the acoustic impedance of the material (material density times the speed of sound through the material). Consequently, steel has a higher reflectivity than does stone or concrete, which has a higher reflectivity than wood. The coarser the sediment, the higher the reflectivity. Therefore, gravel reflects more acoustic energy than sand, which reflects more than silt or clay. The air/water interface is also a very strong reflector of sound; consequently, air entrained in the water column may block the acoustic signal from more distant objects and severely degrade the quality of the sonograph. Propeller wash and wave entrained air may be particularly troublesome if the resultant acoustic turbidity is between the towfish and the target.

15. The slope also affects the strength of the returning signal. As the slope of the target face becomes more perpendicular to the incoming sound wave, the strength of the reflected signal increases. Solitary projections, such as an armor stone sitting on the bottom, will produce a strong dark image on the trackline side of the sonograph and will cast a shadow away from the center line of the record (Figure 4). The acoustic shadow zone (Figure 3), where no signal is reflected, shows up as a white area on the sonograph. This relationship between acoustic shadow and target is reversed for a depression or hole. The sound is not reflected by the hole but reflects off the far side of the hole. Consequently, the shadow is closer to the trackline, and the object's reflection is farther from the trackline (Figure 4).

Vessel speed effects

16. Distortion parallel to the trackline of the towfish occurs due to varying boat speeds. At the speeds recommended for inspection, 3 knots* or less, distortion parallel to the line of travel is negligible. Distortion

* A table of factors for converting non-SI units of measurement to SI (metric) units is presented on page 3. 
perpendicular to the line of travel is a function of the height of the $f$ ish and the distance of the object from the fish and oscillations in these positions. Microprocessor-controlled image processors can be used to print true one-to-one scale sonographs, making both the slant range correction mentioned above and changing the scale of the along track direction to match the slant range scale.

Other aids for interpreting side-scan sonar images

17. Ease of interpreting side-scan sonar image records can be significantly improved by several factors not related to the equipment or physics. First, interpreting side-scan sonar images of structures is much easier if they can be compared to construction drawings, preferably as-builts. The drawings can be used to plan the survey as well as significantly aid interpretation. Second, supplementing the side-scan sonar inspection with limited diver observations can aid in deciphering a questionable feature on the sonograph. Finally, a knowledgeable engineer familiar with the history of a structure can facilitate interpreting the sonograph. 
18. During the past 7 years, CERC has been involved in a number of projects where side-scan sonar was used to document some facet of a coastal structure. Initial work was carried out under the Monitoring Completed Coastal Projects (MCCP) Program at Cleveland Harbor, Ohio. The success of the monitoring effort at Cleveland (Pope and Clark 1983; Patterson and Pope 1983; Rowan, Pope, and Hemsley, in preparation) prompted the use of side-scan sonar at other MCCP projects; Manasquan Inlet, New Jersey; Ocean City, Maryland; Burns Harbor, Indiana; and East Pass, Florida. In addition, Corps districts have used their own and CERC's expertise in inspecting other structures. Additional project sites discussed in this section include Calumet Harbor, Illinois; St. Lucie Inlet, Florida; and Crescent City, California. A summary of selected CERC side-scan sonar experience is presented in Table 1.

Table 1

Selected Summary of CERC Side-Scan Sonar Experience

for Structure Inspection

\begin{tabular}{|c|c|c|}
\hline Location/Structure & Survey Date(s) & Results \\
\hline $\begin{array}{l}\text { Cleveland, } \mathrm{OH} / \\
\text { breakwaters, } \\
\text { revetments }\end{array}$ & $\begin{array}{l}7 / 81 \\
8 / 82 \\
7 / 84\end{array}$ & $\begin{array}{l}\text { Documented condition of dolos rehabil- } \\
\text { itation and imaged a variety of } \\
\text { coastal structures. }\end{array}$ \\
\hline Manasquan, NJ/jetties & $7 / 84$ & $\begin{array}{l}\text { Documented condition of dolos rehabil- } \\
\text { itated jetties. }\end{array}$ \\
\hline $\begin{array}{l}\text { Ocean City, MD/jetty } \\
\text { scour hole }\end{array}$ & $\begin{array}{l}4 / 84 \\
9 / 84\end{array}$ & $\begin{array}{l}\text { Documented coverage of rock layer over } \\
\text { scour prone area adjacent to jetty. }\end{array}$ \\
\hline $\begin{array}{l}\text { Calumet Harbor, IL } \\
\text { Burns Harbor, IN/ } \\
\text { breakwater and } \\
\text { jetties }\end{array}$ & $9 / 85$ & $\begin{array}{l}\text { Inspected cellular cofferdam break- } \\
\text { water, timber cribs, and rubble- } \\
\text { mound breakwater. }\end{array}$ \\
\hline $\begin{array}{l}\text { Crescent City, CA/ } \\
\text { breakwater }\end{array}$ & $\begin{array}{l}10 / 85 \\
7 / 86\end{array}$ & $\begin{array}{l}\text { Inspected dolos rehabilitated } \\
\text { breakwater. }\end{array}$ \\
\hline $\begin{array}{l}\text { St. Lucie Inlet, FL/ } \\
\text { jetties }\end{array}$ & $4 / 86$ & $\begin{array}{l}\text { Inspection of structure to determine } \\
\text { optimum location of sand bypassing } \\
\text { plant. }\end{array}$ \\
\hline East Pass, FL/jetties & $4 / 86$ & $\begin{array}{l}\text { Inspection to determine condition of } \\
\text { structure. }\end{array}$ \\
\hline
\end{tabular}


19. In addition to the CERC experience discussed in this part of the report, side-scan sonar has been used by other investigators for inspecting coastal structures. Some of these applications are addressed in Part IV.

\section{Cleveland Harbor}

20. The eastern 4,400 ft of the Cleveland Harbor breakwater (Figure 7) was rehabilitated with over 29,000 2-ton unreinforced dolosse in 1980 and 1981 (Figure 8). Funding from the MCCP Program provided for a series of monitoring efforts to assess the condition of this structure. An integral part of the monitoring program was the use of side-scan sonar to evaluate the underwater condition of the dolos rehabilitated section. The monitoring effort gained additional significance after an April 1982 storm (with a 100-yr return period
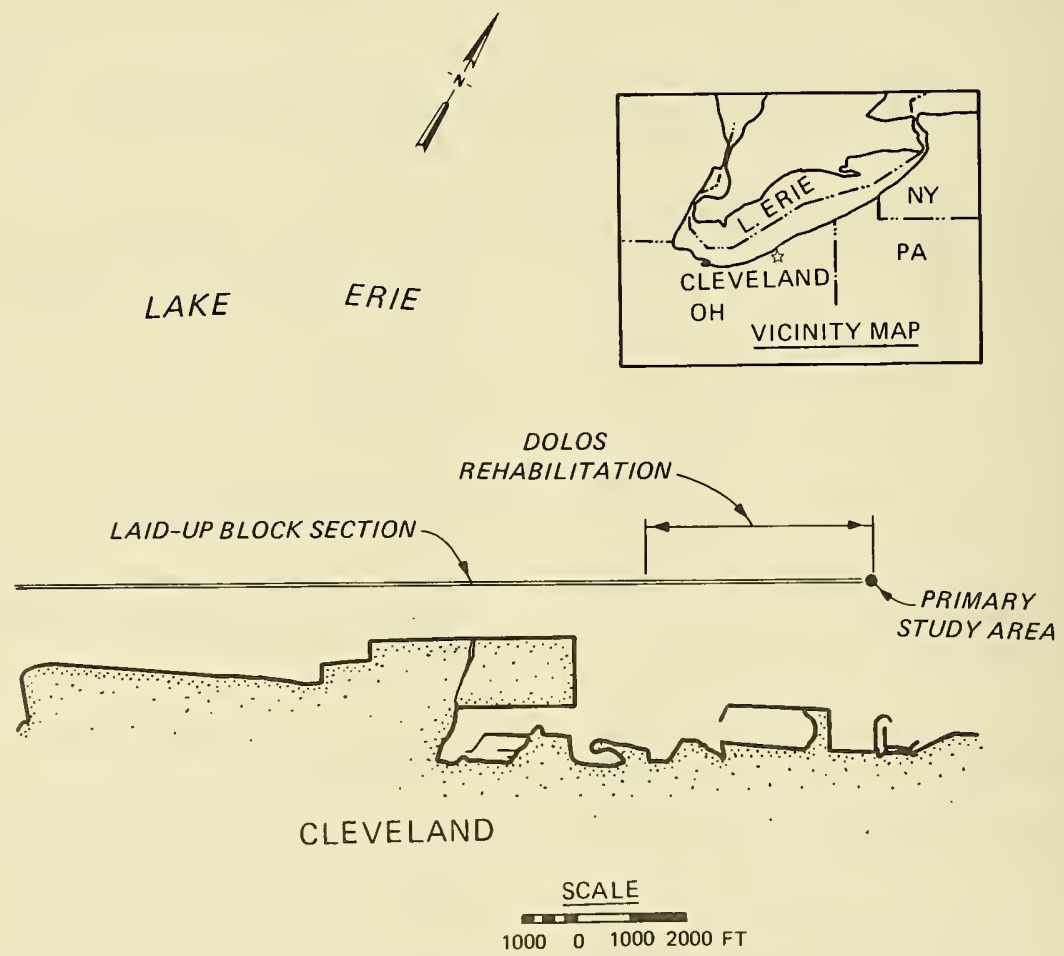

Figure 7. Cleveland Harbor location map 

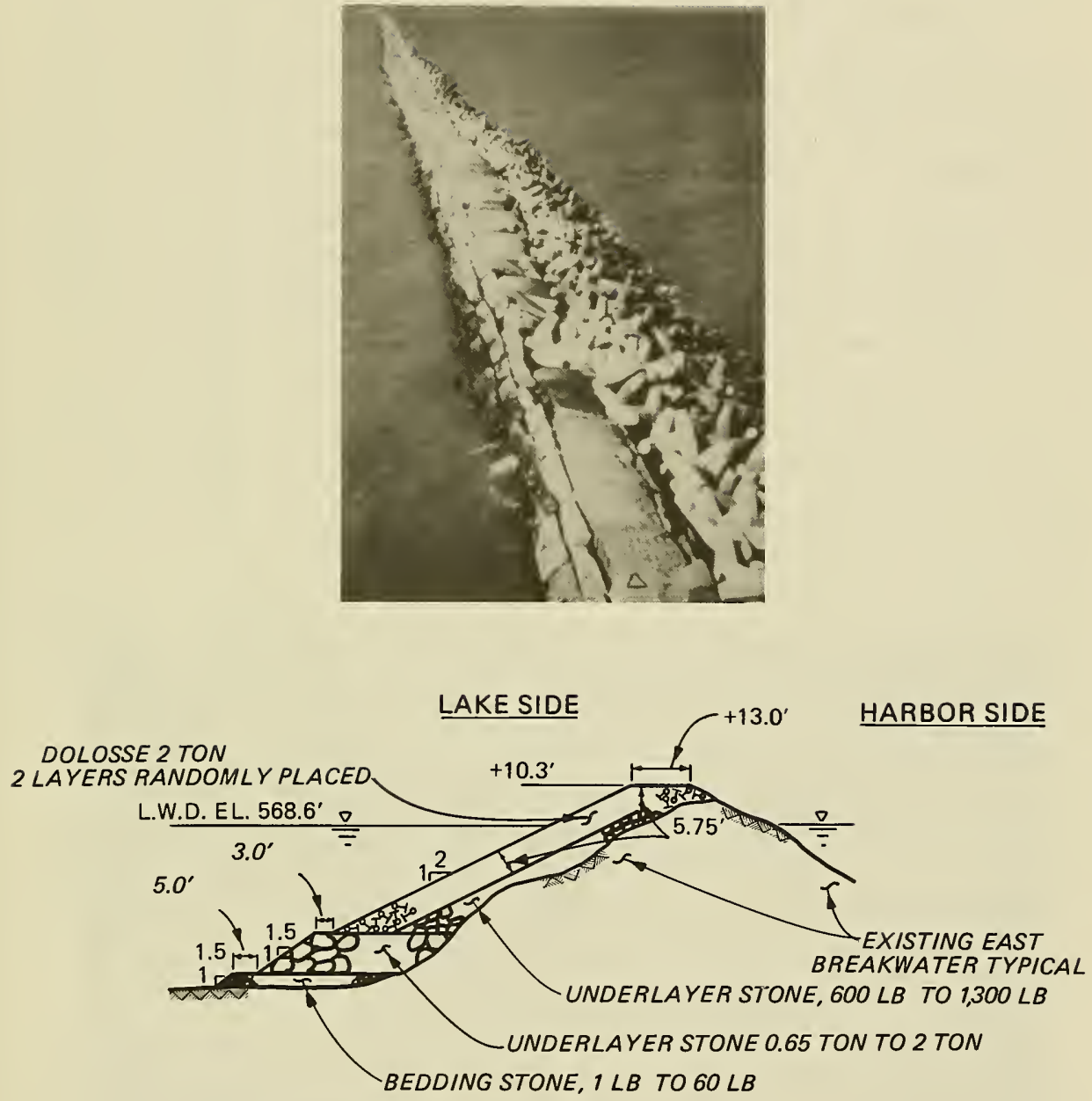

Figure 8. Dolos rehabilitated section of Cleveland harbor breakwater 
water level) damaged the structure. Effects of the high water level on the structure were amplified by large waves which included ice chunks and debris.

21. Side-scan sonar surveys and SCUBA diving inspections were used to assess the underwater condition of the dolos cover and stability of the breakwater's toe berm. A Klein Associates $500-\mathrm{kHz}$ side-scan system was used in April 1981, July 1982, and July 1984 to conduct surveys of the dolos rehabilitated portion of the breakwater and several other structures in Cleveland Harbor. For comparison, several runs with a $100-\mathrm{kHz}$ towfish were made during the 1982 surveys. A more detailed discussion of the comparison between the two frequencies can be found in Part V. In addition, Kucharski and Clausner (in preparation) discuss use of various frequencies for various applications. 22. The results of the first two side-scan sonar surveys (April 1981 and July 1982) are presented in Patterson and Pope (1983). An additional survey was conducted in July 1984. The intent of the side-scan sonar survey portion of the monitoring program was to document changes in the underwater condition of the dolos cover. During the first survey it became apparent that side-scan sonar could only be used as a means of obtaining a qualitative record of the slope and toe characteristics of the structure. A dolos cover has certain characteristics (i.e., random placement, high unit relief and small shape, and high void-to-unit ratio) which make it difficult to identify individual, in-place, units and evaluate their condition. Lessons learned during the April 1981 survey were used to improve results of the July 1982 survey. For example, vessel size and power were increased, allowing more stability in the wave environment (from a 17-ft single engine outboard to a 21-ft twin engine vessel). Also, a short range microwave positioning system was used, and operational techniques were well documented to allow duplication in future surveys. A SCUBA diving survey was recommended for 1983 to check the observations and preliminary evaluations made from the side-scan sonar survey .

23. In August 1983 two dive teams inspected portions of most of the rehabilitated breakwater. General observations made by the divers confirmed several interpretations about the dolos cover which had been made based on the side-scan records. The steep toe and irregular slope were present in the two side-scan sonar record sets suggesting that these characteristics were the result of initial underwater placement.

24. A third underwater inspection consisting of a side-scan sonar 
survey and SCUBA diving inspection was conducted in July 1984. Side-scan sonar records were used to identify sections which appeared to have changed based on comparisons with the earlier records or areas which otherwise appeared to have some unique aspects. The divers were then able to target their inspections to those areas. Figures 9 through 11 are annotated sidescan sonar records from the areas which were verified by diver observation. Figure 9 is a section of the trunk viewed from the water surface looking down the structure slope. Arrow A indicates the location of a high section of dolos cover as shown by the long shadow. There appeared to be a large depression in the cover (as shown by the short shadow) located about halfway down the slope (B). This depression was verified by divers to be an 8 - or 10-ft-wide section with no dolos cover. In addition, in this area the dolos toe and underlayer berm are not well defined in the sonograph. Dolosse appeared to have rolled over portions of the underlayer, and a few were even found on top of the bedding stone.

25. Figures 10 and 11 are from the head section and the transition between the head and the trunk, respectively. Just to the right of arrow $A$ at the waterline (Figure 10), an indentation shows where dolosse were lost during a storm. The dashed line (Figure 10) shows the dolos toe and the exposed

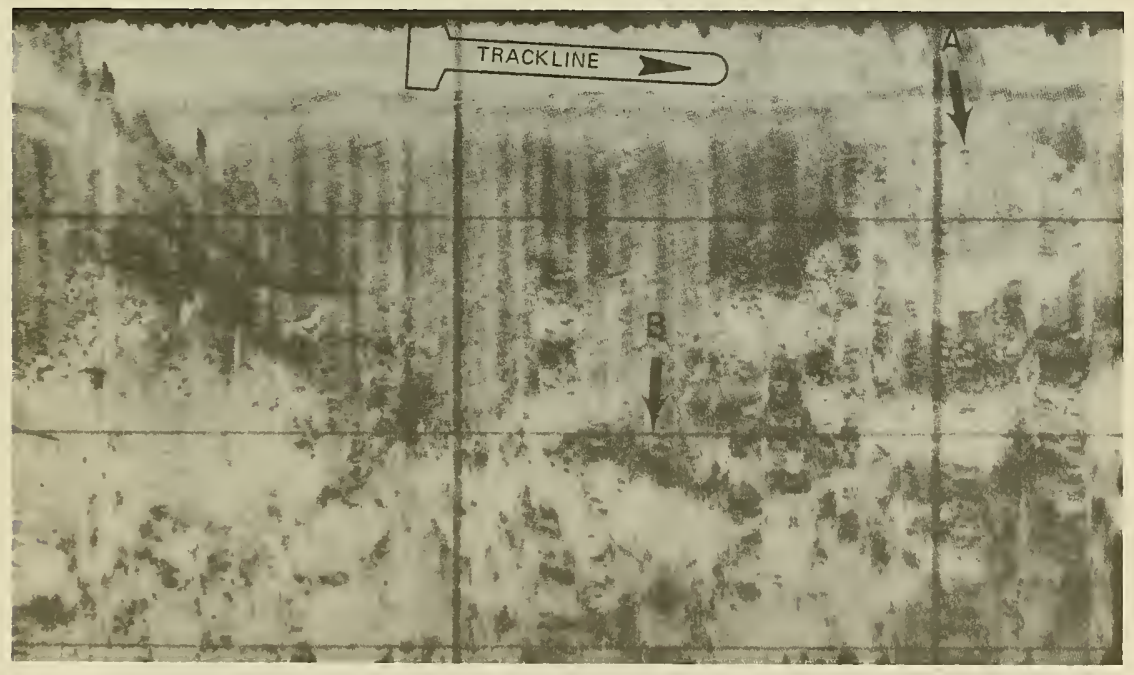

Figure 9. Dolos trunk section of the east breakwater, Cleveland Harbor, Ohio; range $50 \mathrm{~m}$, towfish near surface, $500 \mathrm{kHz}$ 


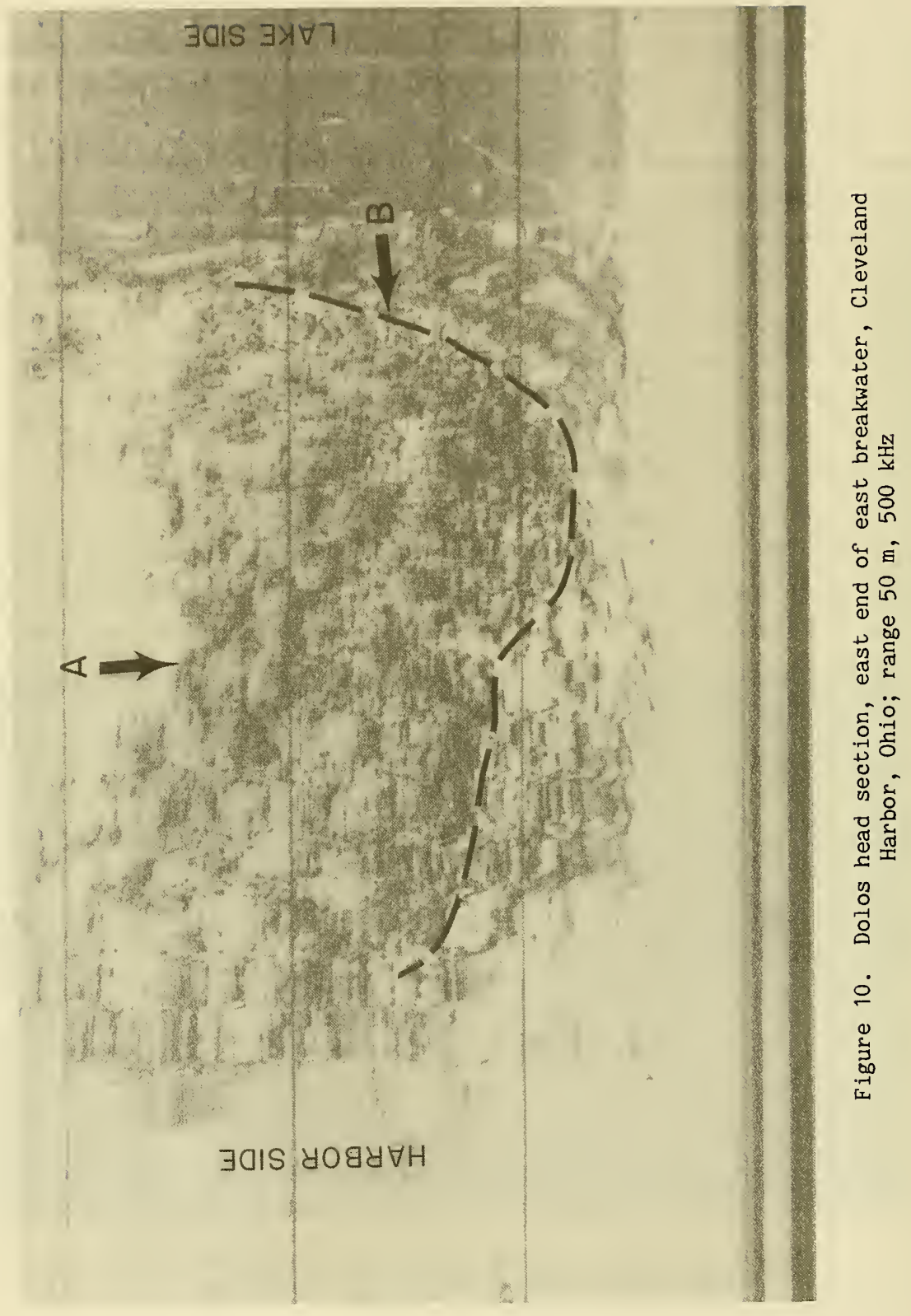




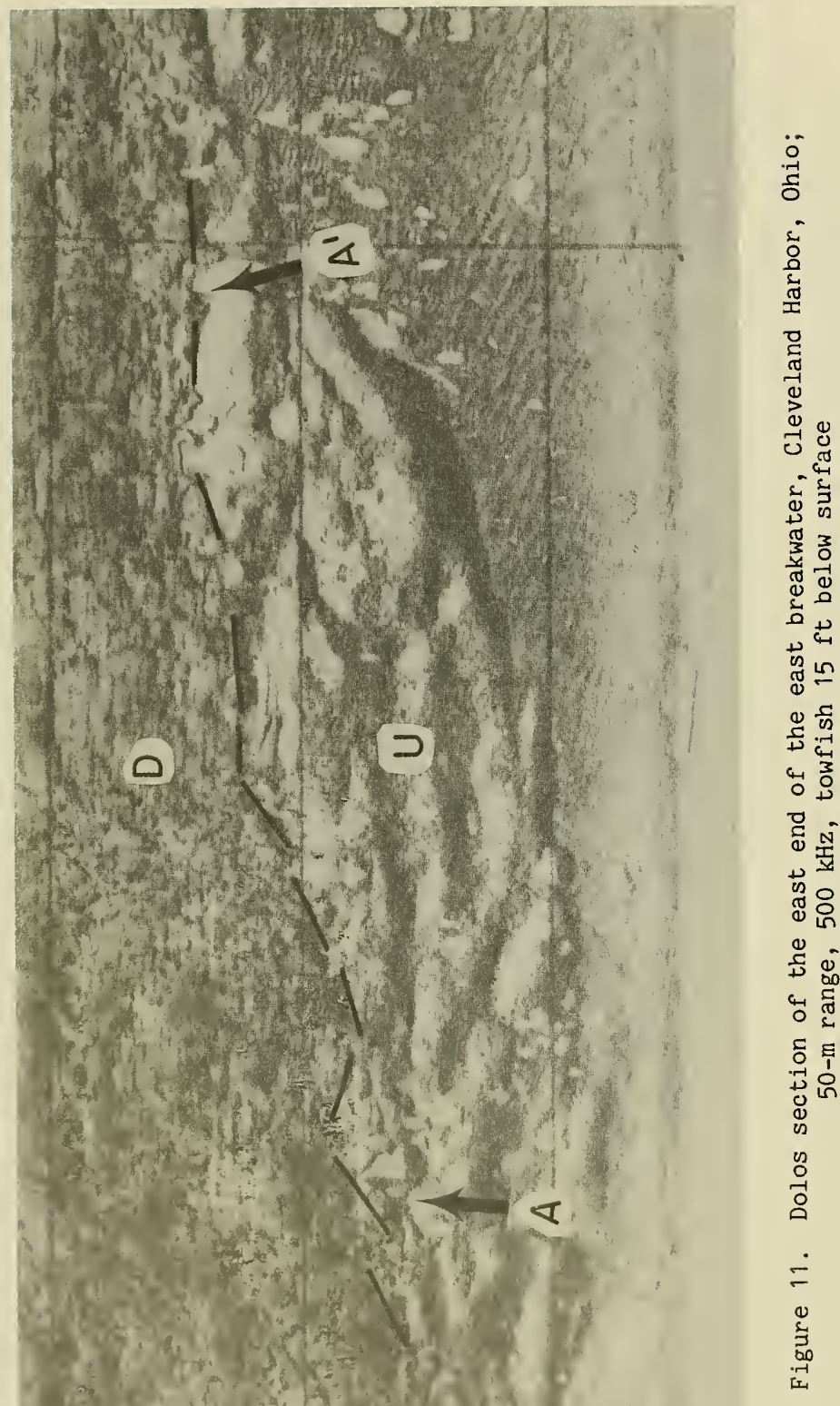


underlayer stone berm. The right side of Figure 10 (Arrow B) shows an area of where the dolos toe is excessively steep and some dolosse placed in 1982 have been lost down the slope. In general, the underwater condition of the head section included a skimpy dolos cover near the toe, numerous "hangers," and more breakage near the waterline. In the transition section (Figure 11), the underlayer toe is very wide and steeply terraced. The sonograph shows transition from the head (left) to the trunk (right). The dolos toe in this area is very steep and well defined as shown by the changes in pattern along line A-A. Divers observed approximately 25 broken dolosse in this section. Although the breakage was random, there was observational evidence of some movement and instability throughout the dolos cover in this section.

26. In summary, the result of the various side-scan sonar surveys and diving inspections was the assessment that the underwater condition of the dolos cover has several flaws as a result of initial placement. Of primary concern are apparent depressions which may be "holes" in the dolos cover and sections where the dolos toe is perched. The side-scan sonar records reveal significant variation in the condition of the structure toe throughout the 4,400-ft-long rehabilitation. There are areas of little or no underlayer berm and other areas where the toe of the dolos cover is very steep. Also of interest is the amount of new breakage and movement observed in both the head section and transition zone during the 1984 inspection. Apparently, the dolos cover in these areas is still dynamic, and progressive deterioration is occurring.

27. Cleveland Harbor offered a unique opportunity to view a variety of coastal structures. In addition to the dolos rehabilitated section, images were taken of the laid-up block breakwater sections, rubble-mound faces of dredged material containment dikes, vertical sheet-pile walls, and timber cribs. Figure 12 shows a laid-up block section (linearity caused by reflection off the edge of the stone blocks). Section A has a uniform slope, and section $B$ has a shadowed upper slope which suggests irregularities and a deteriorated condition. Arrow $C$ shows the waterline and $D$ the toe. Debris and stone blocks are noticeable beyond the toe.

28. An old timber crib section of the west breakwater was inspected from the harbor side (Figure 13). Seams between individual timber cribs were revealed as the acoustic pulse penetrated the joints (A). In addition, those 


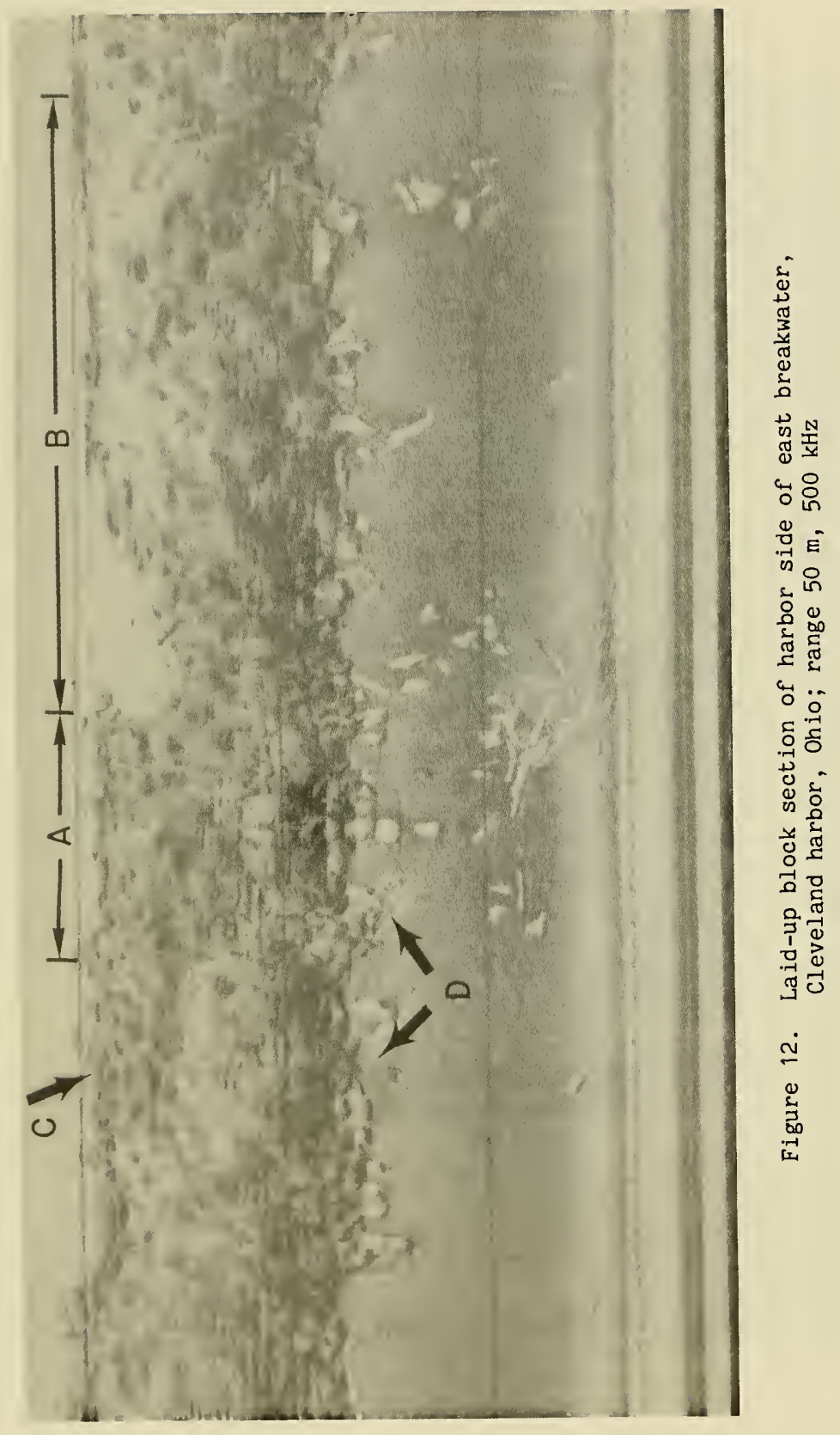




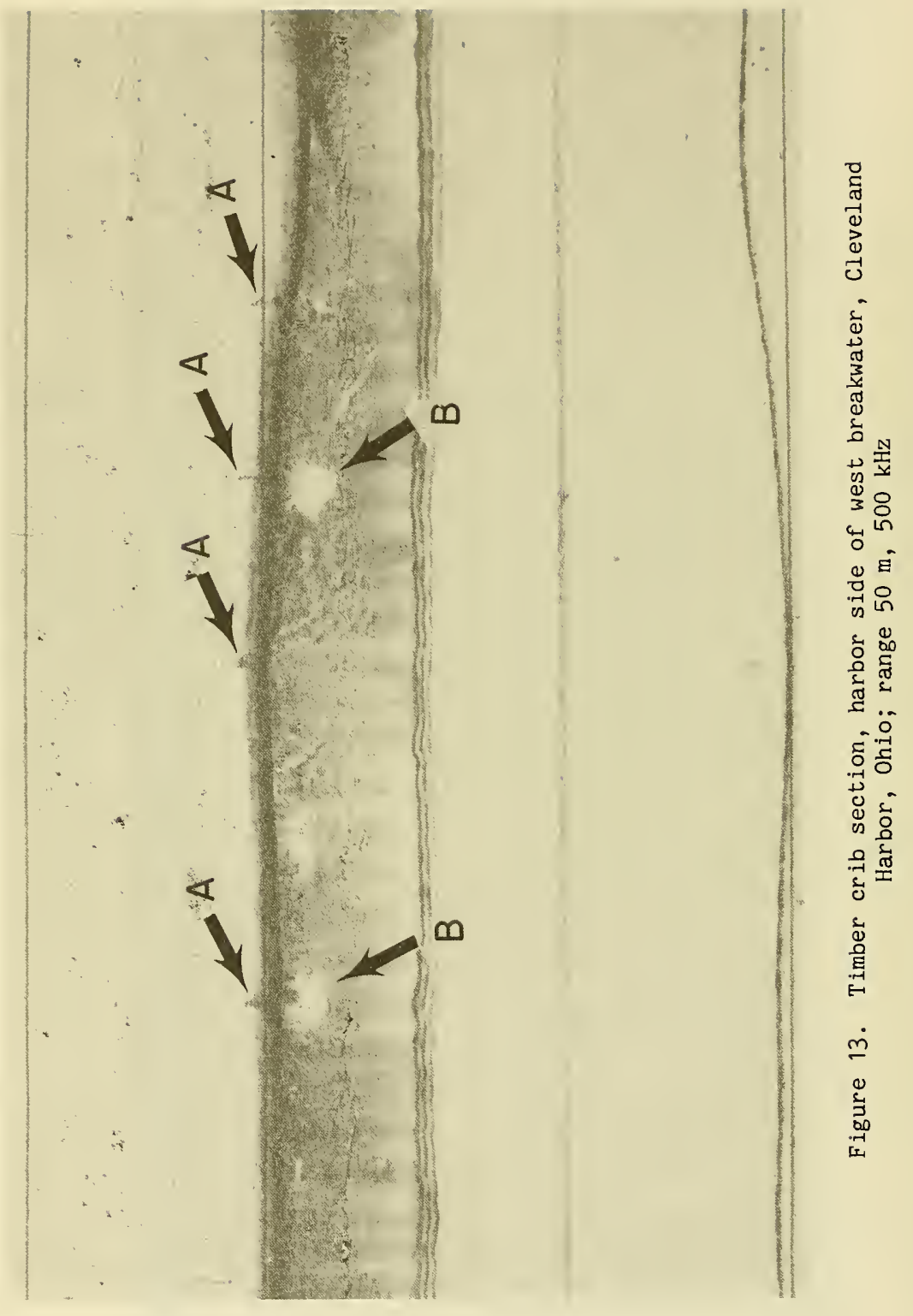


seams which were permeable to wave-induced currents were identified by the scoured depressions in the bottom sediments at the base of several of those seams (B).

\section{Manasquan Inlet, New Jersey, Jetties}

29. In July 1984, CERC performed a side-scan sonar inspection of the jetties at Manasquan Inlet, New Jersey (Figure 14). Between 1979 and 1982 the Manasquan Inlet jetties were rehabilitated with 16-ton reinforced concrete dolos armor units. During the spring of 1984, a storm subjected the structures to waves approaching the design wave height of $25 \mathrm{ft}$. To supplement the ongoing MCCP Program study (Gebert and Clausner 1984, Gebert and Hemsley, in preparation), the side-scan sonar inspection was performed to assess the underwater condition of the structure.

30. The survey was performed from a 40-ft charter fishing boat using a Klein Model 531 system and a $500-\mathrm{kHz}$ towfish. Inspection speeds averaged approximately 2 knots, towfish depth was approximately $5 \mathrm{ft}$, and the range was $50 \mathrm{~m}$. Wind chop with a 2- to 3-ft swell and very heavy recreational boat traffic in the area hampered operations. In spite of these problems, good records were obtained of the channel-side sections of the north and south jetties. Air entrained in the water from boat wakes and breaking waves limited sonograph quality of the south jetty head.

31. Considering the severity of the spring storm, the above water and side-scan sonar interpreted below water condition of the structures appeared to be good overall. Still, the image of the north side of the north jetty (Figure 15) showed two "holes" in the dolos cover (A) and what are probably the tips of 12-ton armor stones (B) projecting above the sand farther to the right. It is possible that these holes were the result of poor quality control rather than the storm. Several targets that may be displaced rocks can also be seen on the record. Diver observations would be needed to positively identify these targets.

32. Two facets of side-scan sonar inspection were highlighted during the Manasquan Inlet work. First, boat traffic is a problem that should be considered when planning a side-scan sonar survey, particularly in areas with a large number of recreational vessels. Second, it is important to conduct 


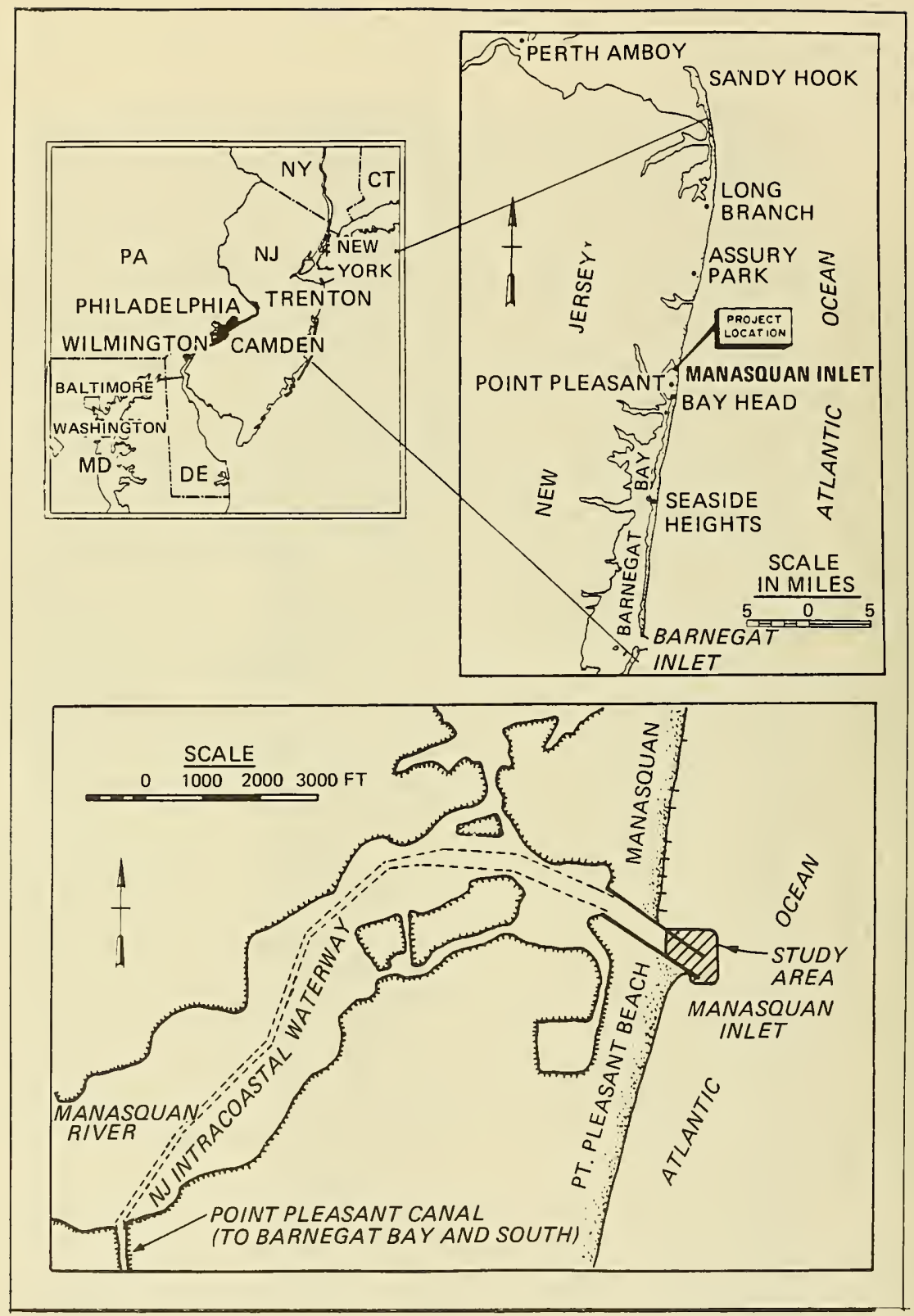

Figure 14. Location map for Manasquan Inlet, New Jersey (after Gebert and Clausner 1984) 


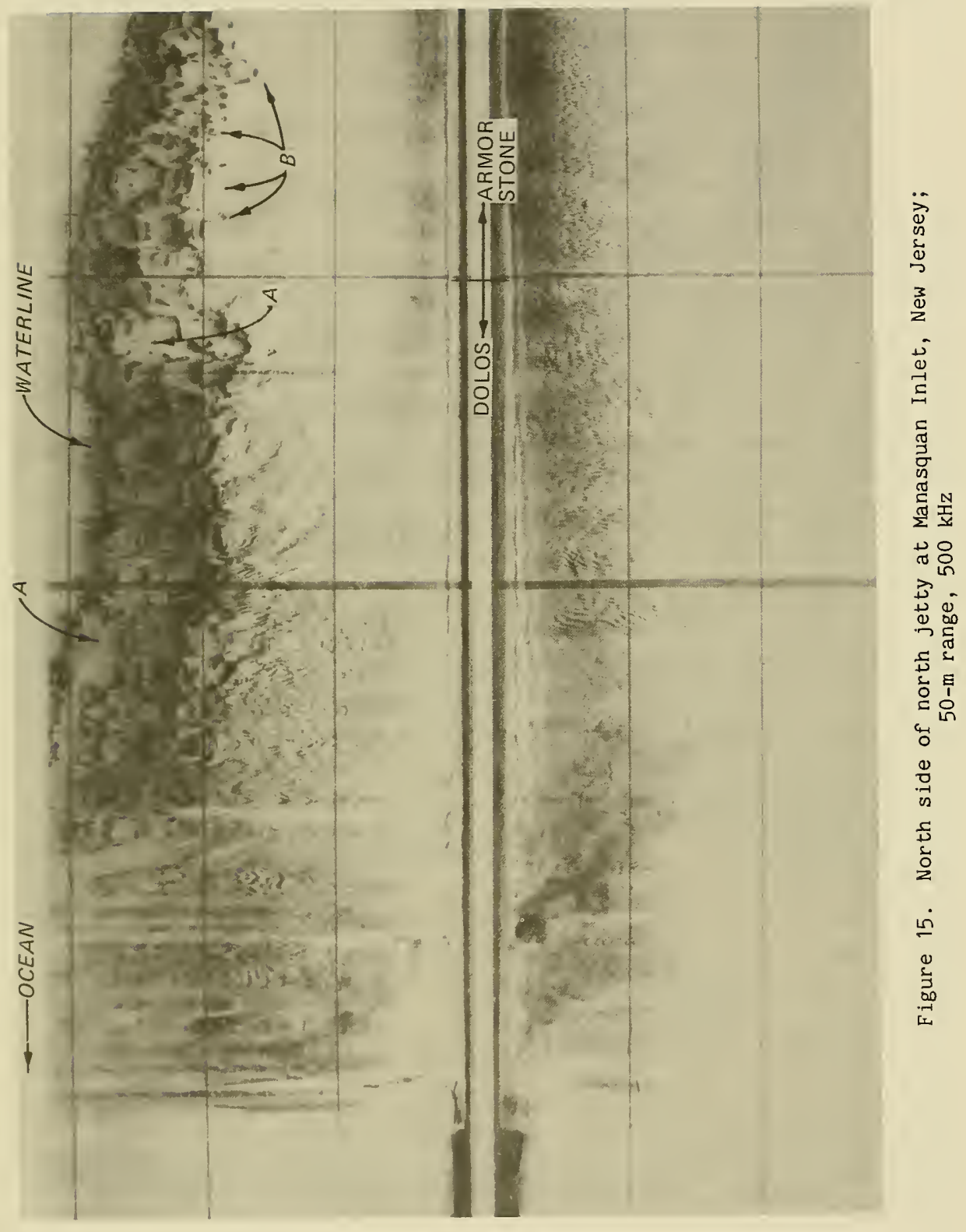


the initial survey as soon as possible after construction. Because the initial side-scan sonar survey was not completed until after a severe storm, it was impossible to determine if the suspected structural flaws were due to the storm or the result of initial construction.

\section{Ocean City Inlet, Maryland, South Jetty}

33. In September 1984 CERC assisted the US Army Engineer District, Baltimore (NAB), in inspecting a contractor's efforts to repair a scour hole along the channel side of the Ocean City Inlet south jetty (Figure 16). The integrity of the south jetty had been threatened by a tendency for tidal flow to channelize along the north side of the outer jetty section causing a deep scour hole. As part of a major rehabilitation of the entire south jetty, NAB required the contractor to hydraulically place sand fill into the scour hole, seal the top of the scour hole with a 24 -in. stone blanket, and construct a stone berm at the base of the existing jetty. The stone blanket was specified as a 2,000-ft-long, 200-ft-wide rectangle. The purpose of the side-scan sonar inspection conducted was to document the sand filling operation and the uniformity of the stone cover.

34. The inspection was conducted from a 24-ft outboard. A vessel of this size was needed to provide sufficient maneuvering control in the strong tidal currents at the inlet. A Klein $500-\mathrm{kHz}$ system was used with a $50-\mathrm{m}$ range, a towfish depth of 5 to $10 \mathrm{ft}$, and a tow speed averaging 2 knots. A microwave positioning system was used for position and navigation control. Wave and current conditions reduced the surveying window, making surveying possible only during the 2 to $3 \mathrm{hr}$ before high tide when the tidal current through the entrance was relatively slack. During the slack period associated with the low flooding tide, wave breaking on the jetties entrained air in the water column, severely reducing record quality. On ebb tide flows, opposing waves and currents created steep waves at the entrance, causing excessive towfish motion.

35. A series of side-scan sonar surveys spread over two days was conducted to define the areas of stone cover. No single survey could cover the entire area due to the contractor's derrick barge blocking access to the control portion of the stone cover during the first day of surveying. Individual surveys were manually corrected for slant range and target position and 


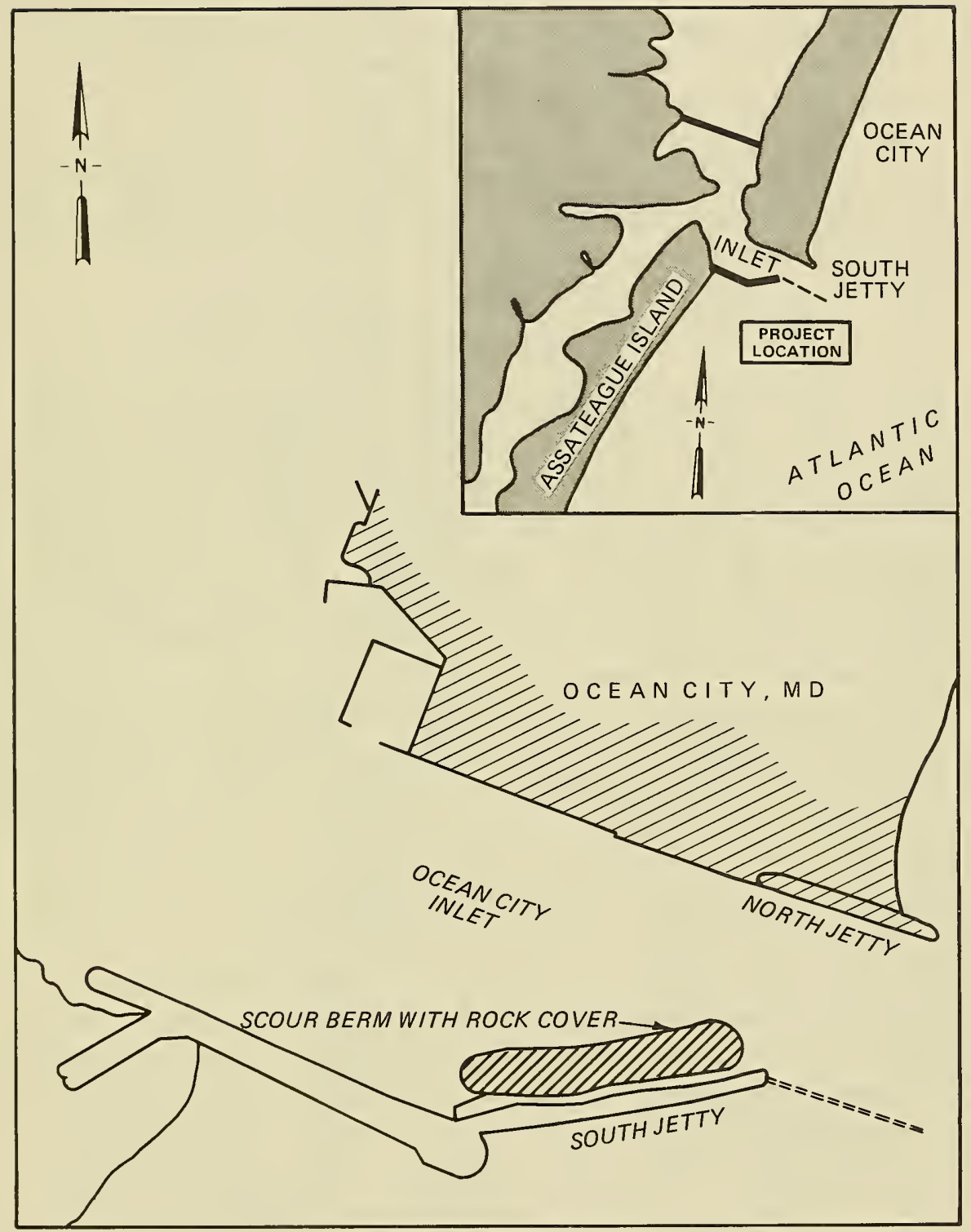

Figure 16. Location map for Ocean City Inlet, Maryland 
then composited to create a map showing cover over the specified stone blanket area (Figure 17). Divers verified the results shown on the side-scan sonar images by traversing along the three tracklines shown in the figure. Some of the areas identified as sketchy cover were determined to be areas with adequate stone cover but where drifting sand had covered the stone.

36. The Ocean City experience showed how side-scan sonar can be used as a quality control inspection tool. Another important lesson learned was the need to schedule surveys around the tidal cycle to limit current velocities at the time of the survey and to take advantage of the water depths.

\section{Burns Harbor, Indiana, and Calumet Harbor, Illinois}

37. During September 1985, the breakwaters at Calumet Harbor, Illinois, and Burns Harbor, Indiana (Figure 18), were inspected with side-scan sonar to assess their conditions. Specifically, the surveys were conducted as a part of US Army Engineer District, Chicago's (NCC's), studies in preparation for rehabilitation of the breakwaters. Morang's (1987) report provides a good example of the detail possible when time and conditions allow a complete structure inspection using side-scan sonar. The following paragraphs review pertinent sections of that report.

38. Both surveys were conducted using an EG \& G Model 260 image correcting side-scan sonar. The signal processing capabilities of the unit allowed it to produce images corrected for slant range, ship speed, and altitude. Consequently, the resulting records show an accurate plan view of the lake bottom and structural features. The surveys were run using $100-\mathrm{kHz}$ transducers, and images were recorded at 25- and 50-m ranges. Surveys were conducted from a US Army Engineer District, Detroit (NCE), survey vessel, approximately $50 \mathrm{ft}$ long and at speeds of 2 to 3 knots. Positioning was accomplished by observing passage of 100-ft station markers painted on the breakwater and by manually triggering the event marker at every fifth station. The triggering was time delayed to allow the towfish to be even with the station, allowing accuracies estimated to be $\pm 15 \mathrm{ft}$. Survey conditions were excellent with waves of less than $1.5 \mathrm{ft}$.

39. Sections $A, B$, and $C$ of the Calumet Harbor breakwater were surveyed. Sections A and B consist of wooden cribs (Figure 19), completed in 1904 and capped with concrete structures during the 1920's. Section C, the 


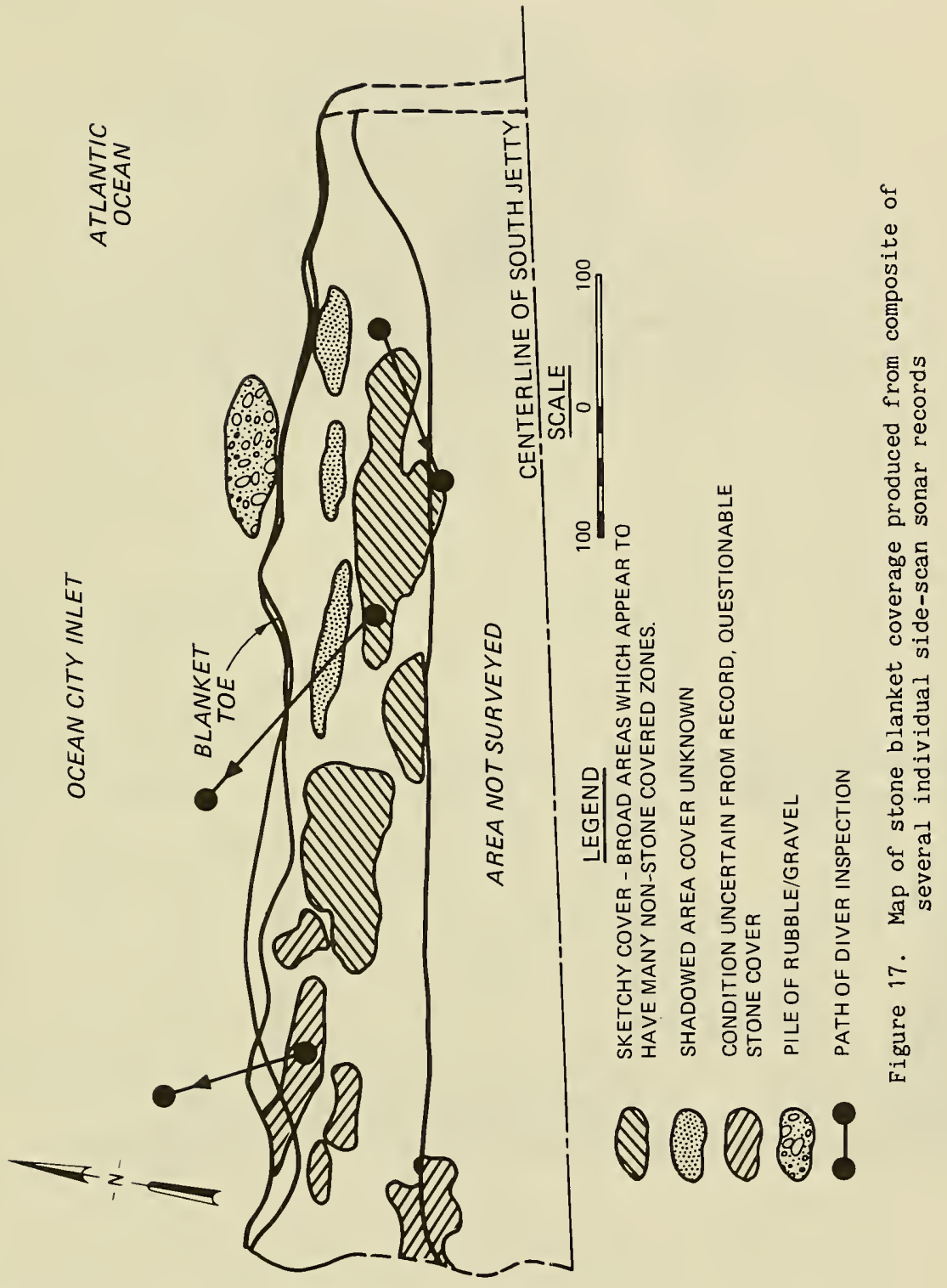



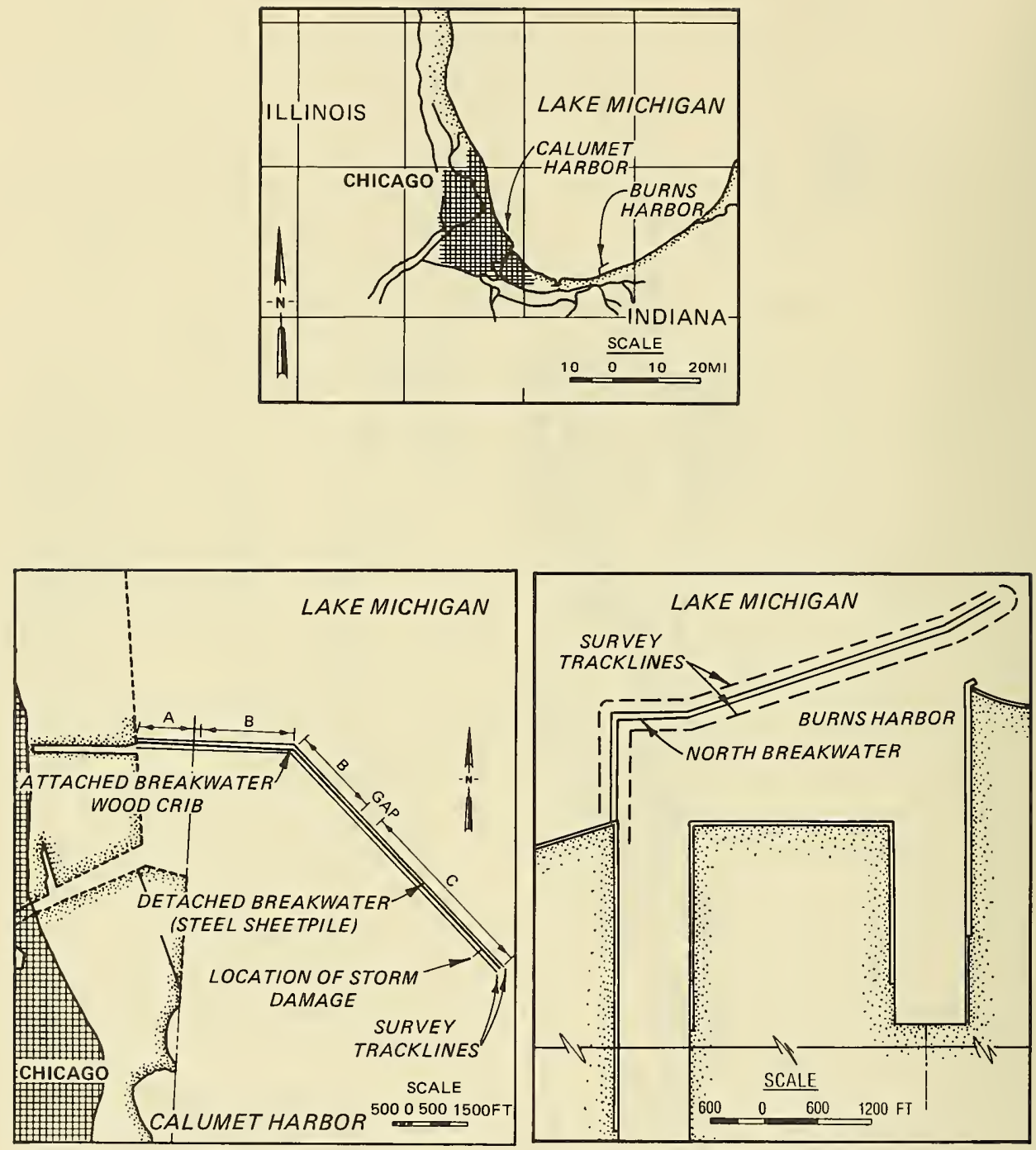

Figure 18. Location map for Calumet Harbor, Illinois and Burns Harbor, Indiana 


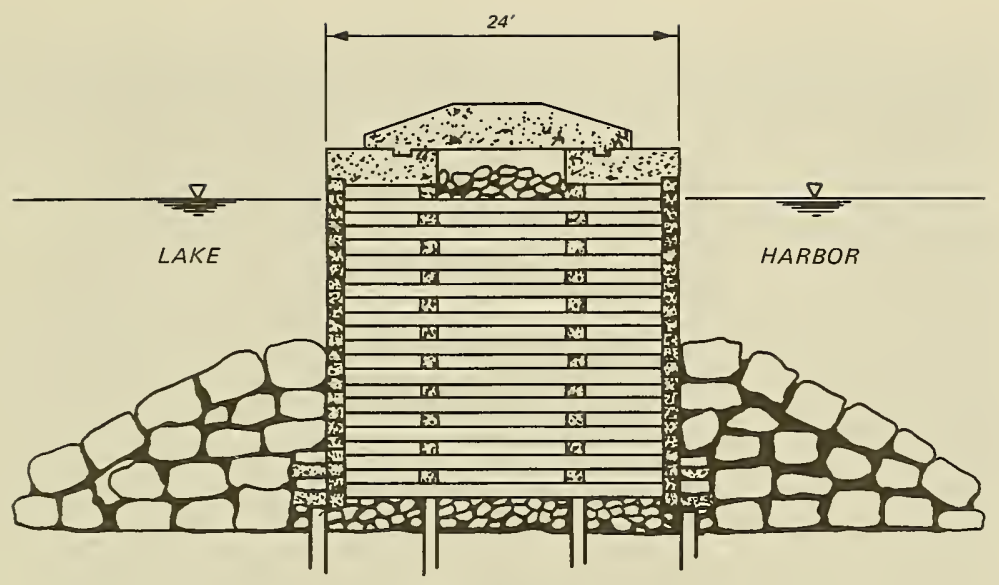

SECTION A

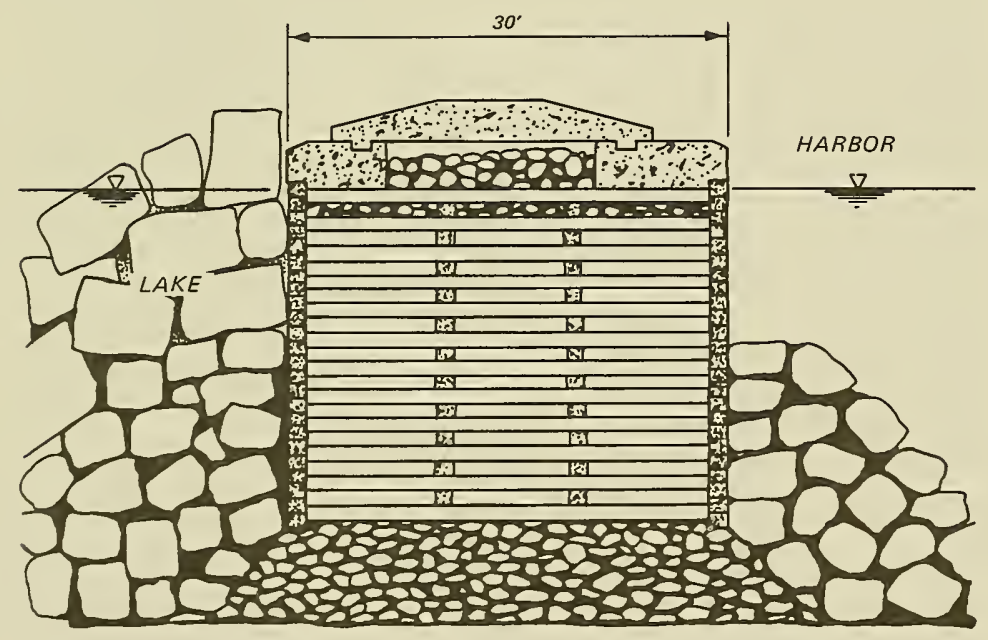

SECTION B

Figure 19. Timber crib construction typical of sections $A$ and $B$ of the Calumet Harbor breakwater 
detached breakwater section, consists of 131 stone-filled, sheet-pile diaphragm cells (Figure 20). According to NCC reports, areas of hard limestone limited pile penetration into the sandy lake floor to approximately $7 \mathrm{ft}$.

\section{BREAKWATER \\ STEEL SHEET PILE \\ DIAPHRAGM \\ AS ORIGINALLY \\ CONSTRUCTED}

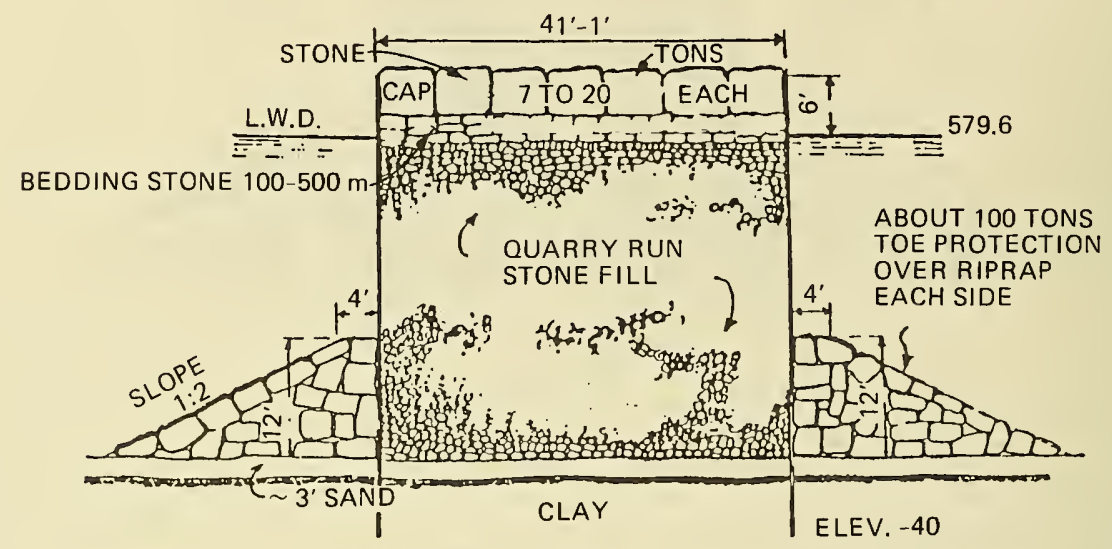

Figure 20. Diaphragm sheet-pile cell construction typical of section $\mathrm{C}$ of the Calumet Harbor breakwater

40. Images of the harbor side of section A reveal a section of a crib which appeared to have been displaced slightly inward. The lakeward face of section $A$ had numerous irregular reflections occurring up to $10 \mathrm{ft}$ behind the face of the breakwater (Figure 21). It is hypothesized that these reflections occur at gaps in the damaged face of the cribs where the acoustic signal has entered a void and has reflected from the fill material within the cribs similar to the records of the cribs in Cleveland Harbor shown in Figure 13.

41. Records of the harbor side of section $B$ also show several areas were the wooden cribs have may been damaged. Several fan-shaped deposits of stone and gravel extend up to $50 \mathrm{ft}$ from the base of the breakwater. These may be debris cones of fill that have flowed out from holes in the damaged cribs. This occurrence is corroborated by the Calumet Harbor Reconnaissance Report (NCC 1985), which states that there are voids in some of the cribs in this area based on above water inspections.

42. The round sheet-pile cells can be clearly seen in the records (Figure 22), and they appear to be in good condition. A breach is evident in 


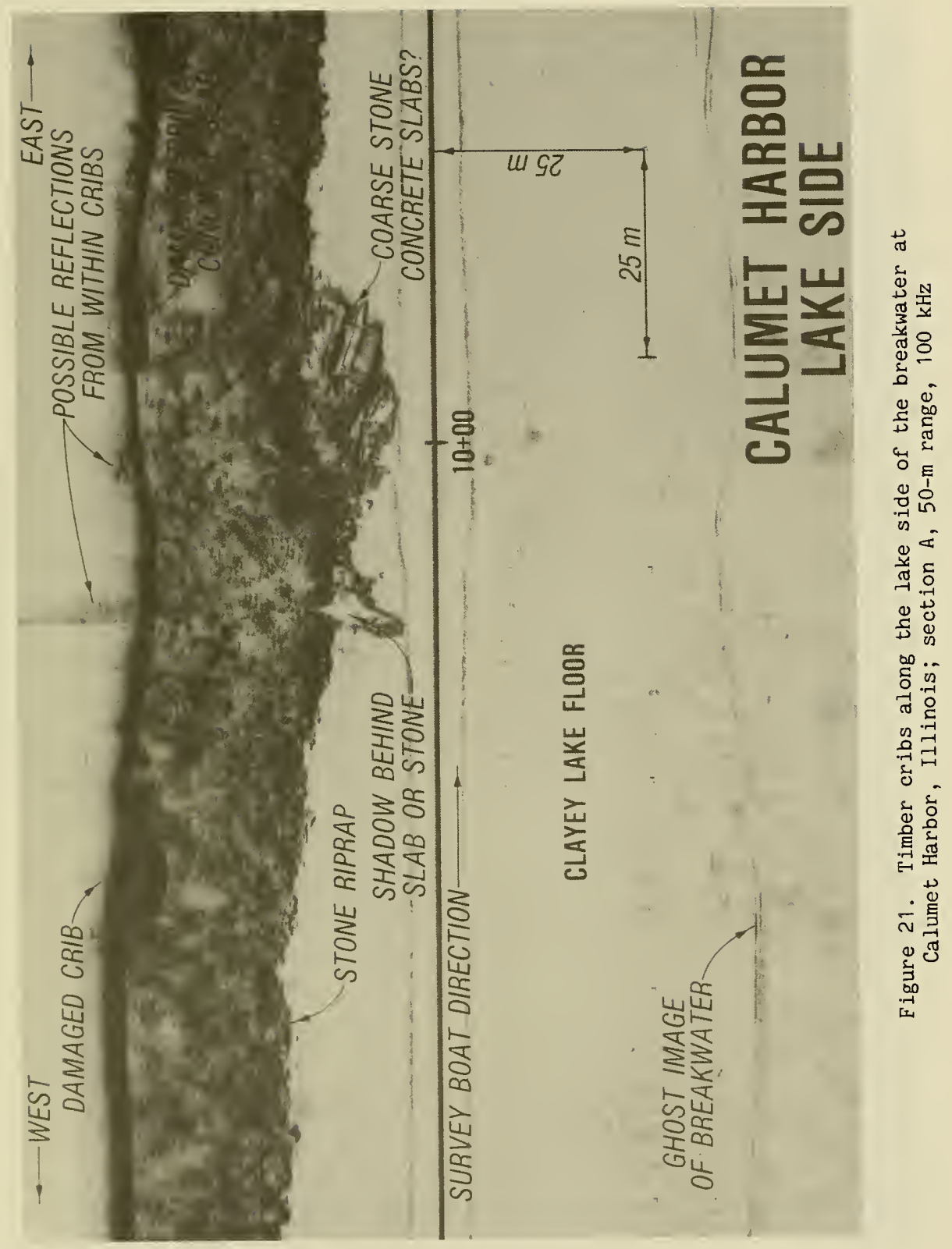




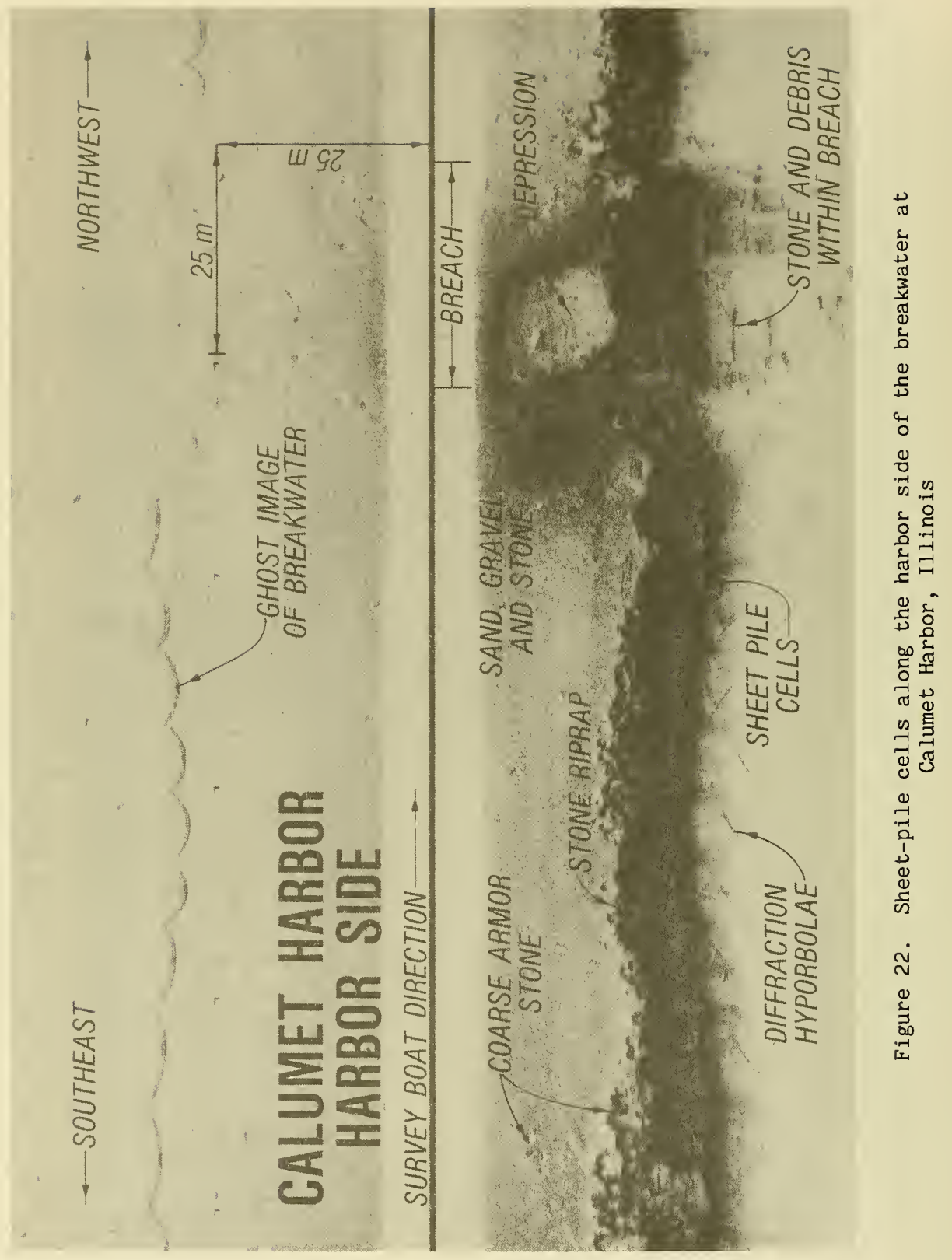


Figure 22 where the cells failed in a 1984 storm. Because of the intensely strong signal return from the vertical sheet-pile walls, minor damage to the walls, such as gaps a few inches wide, may be masked or not resolved. The faint lines and texture on the cell images are diffraction hyperbolae and noise. Diffraction hyperbolae often occur from strong circular reflectors of acoustic energy (like steel pipes and circular sheet-pile cells) due to reflections of energy from the horizontal side lobes. Another unusual feature shown in Figure 22 is the ghost image caused by cross talk from the other channel. Cross talk occurs when the reflected sound energy is so strong that it causes the transducer on the opposite side of the towfish to vibrate.

43. The Burns Harbor breakwater, constructed between 1967 and 1970, is a multi-layer rubble-mound design using 10- to 16-ton limestone blocks on the exposed surfaces (Figure 23). Soil borings prior to construction indicated that approximately $10 \mathrm{ft}$ of soft clay were underlain by much harder clay. Before construction, the soft clay was to have been excavated and replaced with a sand mat which was to extend at least $30 \mathrm{ft}$ beyond the toe of the structure. The excavated clay was disposed onto the lake bed about 150 to $300 \mathrm{ft}$ from the toe of the structure in 50-ft depths.

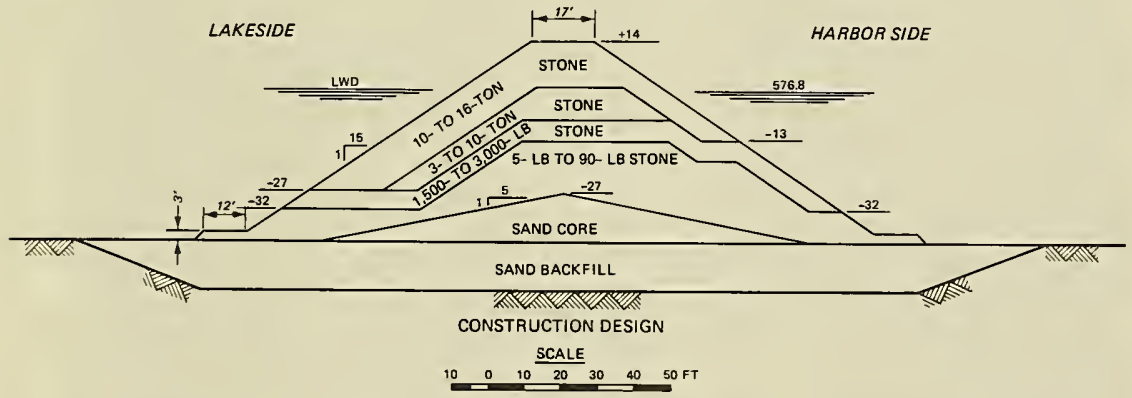

Figure 23. Cross section of Burns Harbor breakwater

44. The lakeside survey conducted in 1985 was not able to provide conclusive evidence of a sand mat extending beyond the base of the structure (Figure 24); also, no conclusive evidence of a sand mat was found on the harbor side. Areas of sand waves occur at distances greater than $30 \mathrm{ft}$ from the base of the structure, but these are believed to be veneers of sand moved by waves and currents over a predominantly clay lake bottom. It is possible that wave action could have redeposited soft clay sediments on top of the sand 


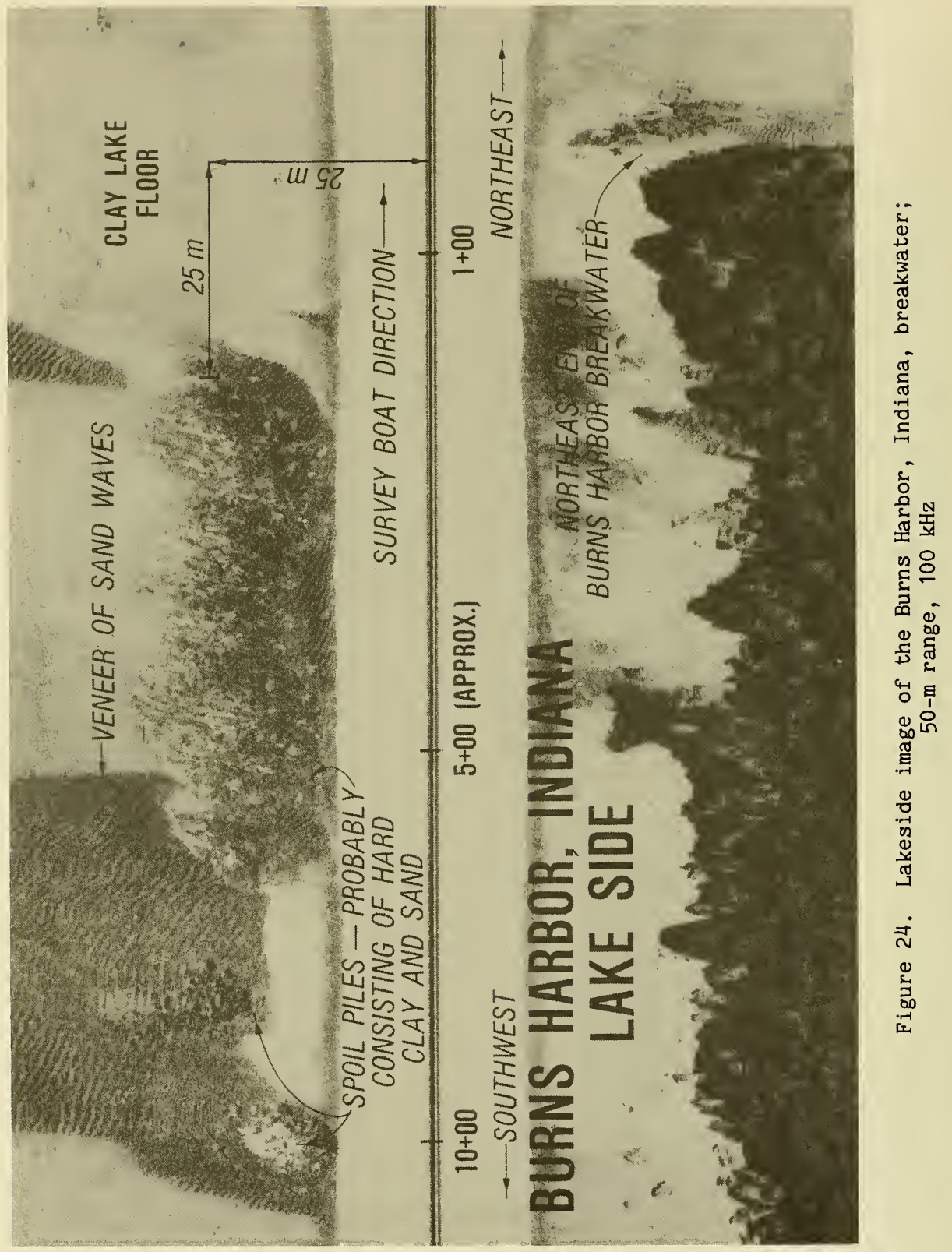


mat on the lakeside and harbor side. Another possibility of why the sand mat was not seen, if it does exist, may be due to the self-tuning characteristics of the EG\&G side-scan sonar. To provide a usable image of the highly reflective rubble structure, the instrument gain may have been turned down to such a degree that the sand mat next to the structure was not visible. To conclusively answer the question of the existence of the sand mat would require that a sediment sampling program (preferably cores) be conducted. In fact, limited bottom sampling will provide the necessary ground truth measurements needed to interpret bottom characteristics seen on many side-scan sonar images.

\section{Crescent City, California, Breakwater}

45. The outer breakwater at Crescent City, California (Figure 25), was rehabilitated in 1974 with 42-ton dolosse. Since that time the structure has experienced damage regularly, due to the severe wave climate. To assist the US Army Engineer District, San Francisco, in evaluating the extent of the damage and as part of the monitoring phase of the "Measurement of Prototype Forces on Dolosse at Crescent City, California," work unit, the Coastal Engineering Research Center (CERC) conducted a series of side-scan sonar surveys.

46. The first survey was conducted in October 1985. An EG\&G digital side-scan sonar, model 260, was used along with a 100-kHz towfish. A 26-ft sport fishing boat was used as the towing vessel, with tow speeds ranging between 3 and 5 knots depending on the range used on the recorder.

47. Environmental conditions were excellent considering the normal wave climate along the northern California coast (a $0.8-\mathrm{ft}$ swell with a 2-ft wave). The combination of wave direction, size, and vessel size, caused the vessel to slide off the swell resulting in some distortion of the record. An offset distance of approximately $100 \mathrm{ft}$ from the center line of the structure was maintained.

48. Apparently the high wave energy of this region had swept the bottom fairly clean, leaving a featureless sand veneer. There was little evidence of exposed dolosse pieces or other debris in the record (Figure 26). A large offset in the toe of the structure (point $A$ on both this figure and Figure 27) can be seen at the transition between dolos cover and stone cover. This offset does not correspond to any failure above the waterline; however, there 


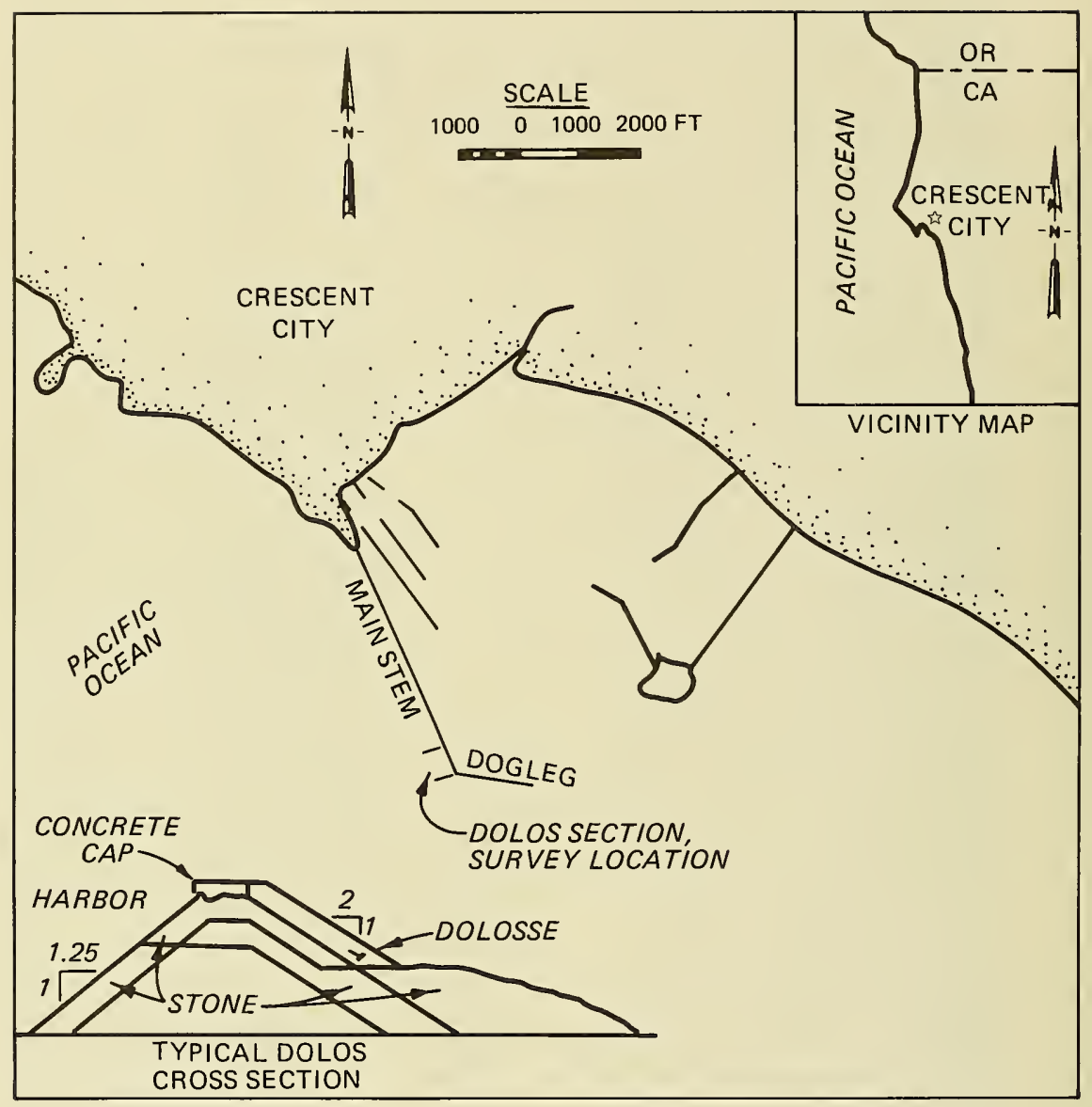

Figure 25. Breakwater at Crescent City, California 


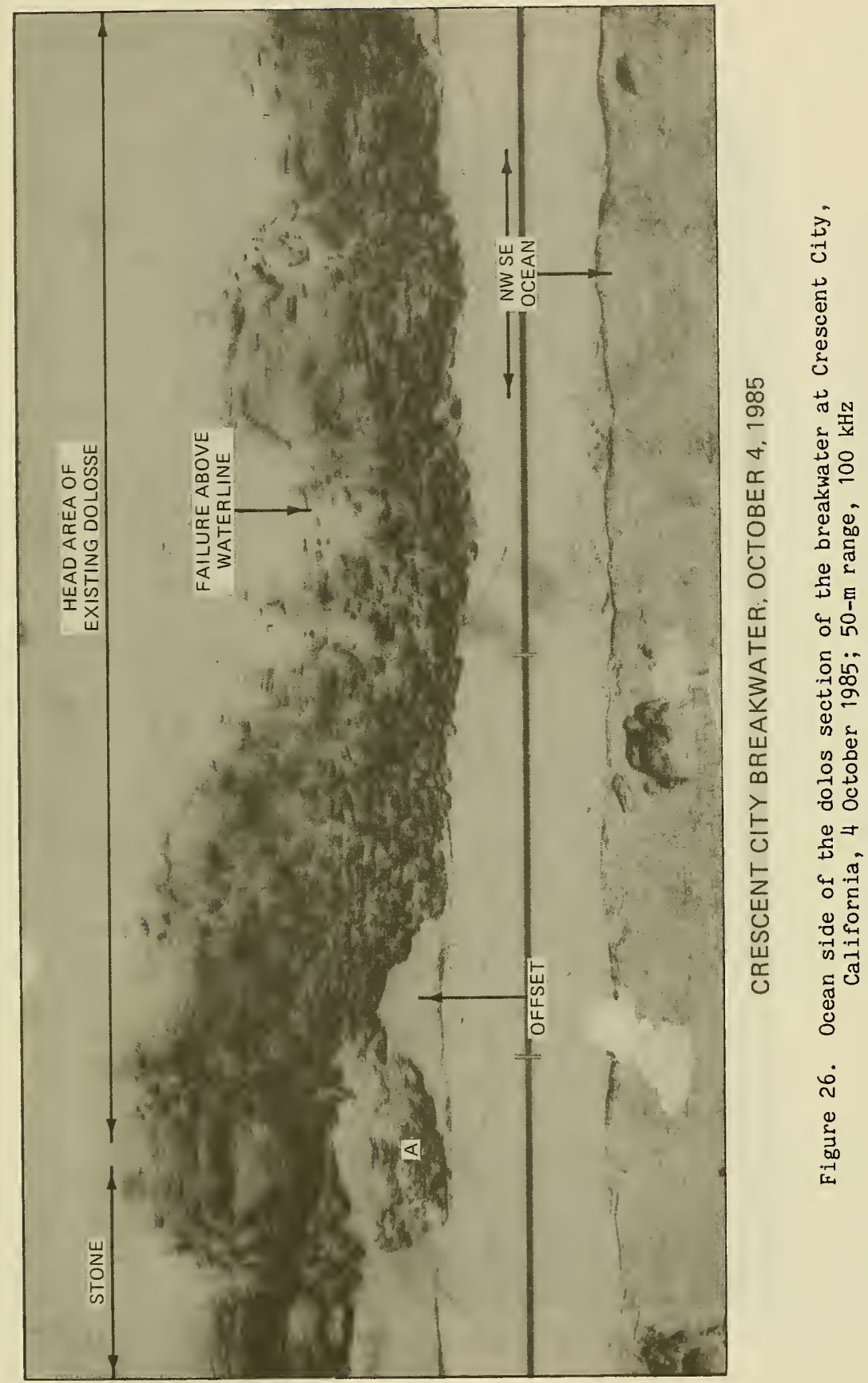




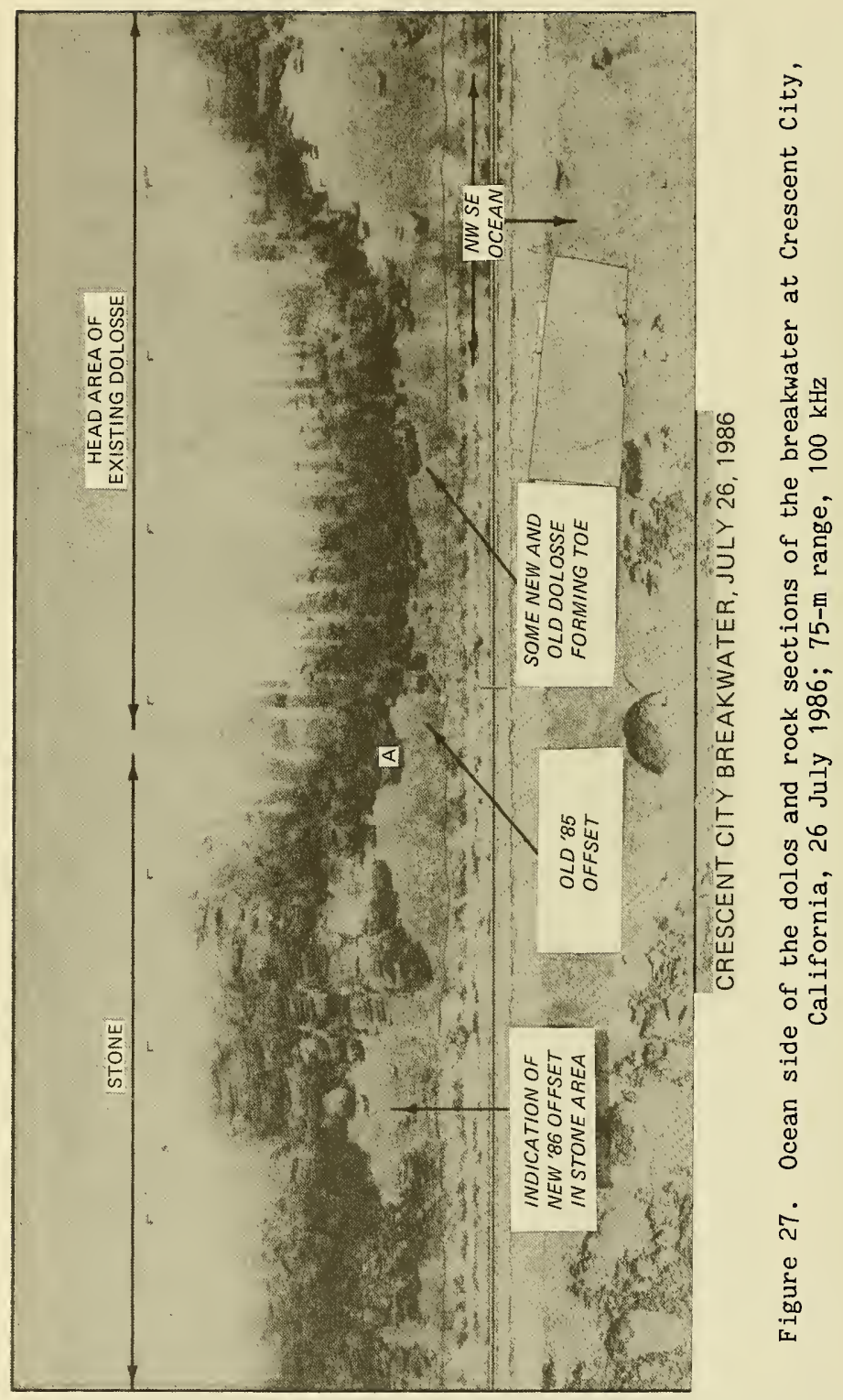


is a failed zone located approximately $100 \mathrm{ft}$ to the right of the toe offset. Failure above the waterline has pushed the armor units out toward the ocean. (Note the offset at left center; point $A$ is in the same location in this figure and Figure 27 for reference.)

49. A second survey in July 1986 (Figure 27), shows essentially the same results, but with some important differences. (Figure 27 was taken at a $75-\mathrm{m}$ range, while Figure 26 was taken at a 50-m range; consequently distances perpendicular to the line of travel are compressed on Figure 27.) By the time the second survey had been taken, a contractor had already started to replace some of the damaged and missing dolosse, making the toe well defined. Also, the above-water failure zone had been repaired. There appears to be a section farther inland that exhibits the same conditions as offset shown in the 1985 survey (Figure 26). However, Figure 26 does not extend far enough to the left (northwest) to show this section. The condition of this hole will be examined closely in future surveys.

50. The severe wave climate at Crescent City makes obtaining good quality side-scan sonar records a difficult and potentially dangerous task. Use of a $100-\mathrm{kHz}$ towfish is one step that can be taken to improve record quality. The 100-khz images are usually less sensitive to motion (often wave induced) than are the $500-\mathrm{kHz}$ images. Another potential method for collecting data at Crescent $\mathrm{City}$ and other high energy wave environments would be to deploy the towfish from the basket of a crane, significantly reducing the wave effects on the towfish. This technique has been used on offshore oil platforms and is described in detail in Kucharski and Clausner (in preparation). Helicopters have also been used as towing vessels for side-scan sonars. However, they would be more dangerous than a crane due to the potential for an accident should the towfish become lodged in the structure armor.

\section{St. Lucie Inlet, Florida, Sand Bypassing Study}

51. In April 1986, CERC performed a field study at St. Lucie Inlet, Florida (Figure 28), in support of a US Army Engineer District, Jacksonville project. The purpose of the study was to determine the optimum location for a sand bypassing plant planned for the inlet. Sand passing through the weir section in the north jetty forms a spit on the southern end of the northern barrier island which eventually shoals in the channel making navigation 


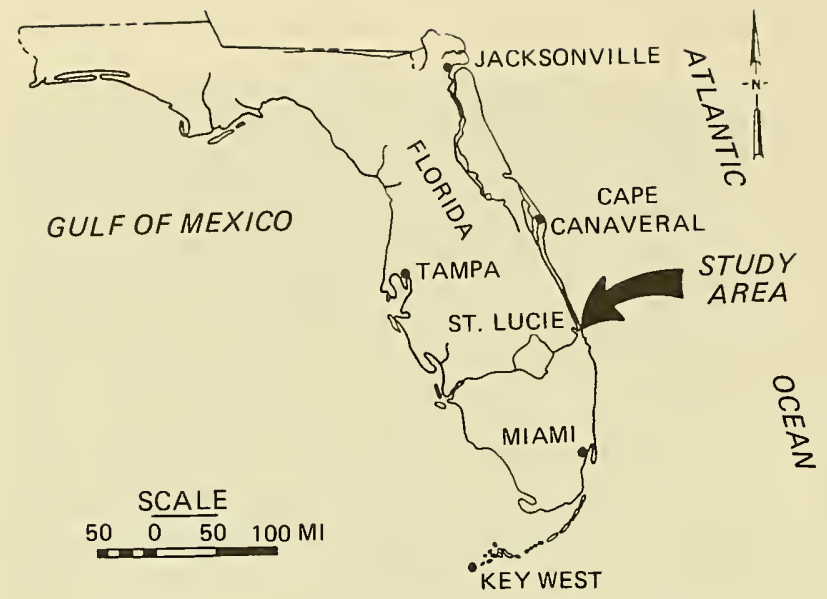

ST. LUCIE INLET, FLORIDA
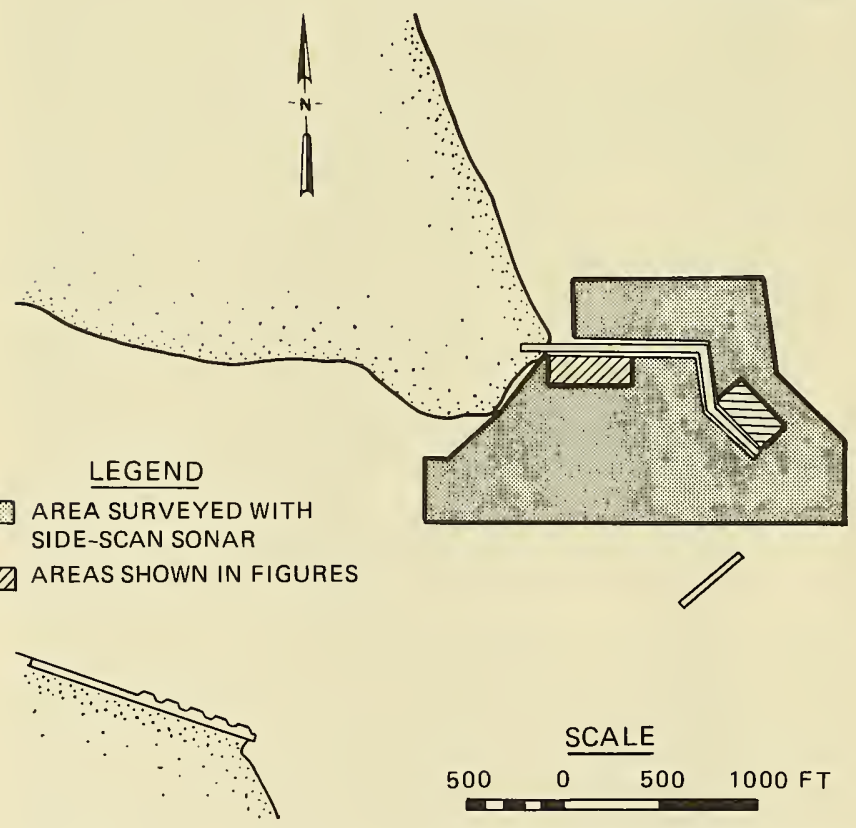

SCALE

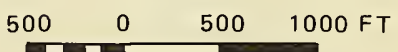

Figure 28. Location map for St. Lucie Inlet, Florida 
hazardous. Side-scan sonar was used to document any visual evidence of active sand movement zones and to help in selecting a location of the intake for the bypassing plant. In addition, the area around the jetties was checked to determine sand transport pathways.

52. The side-scan sonar inspection of the site was performed using a Klein $500-\mathrm{kHz}$ system with the majority of the images taken at a range of $50 \mathrm{~m}$. The towing vessel was a 26-ft Mako fishing boat (open cabin, with center console), and average towing speed was 2 to 3 knots. Typical $\mathrm{fish}$ depth was $4 \mathrm{ft}$ below the surface. Water depth at the site' ranged from 3 to $20 \mathrm{ft}$, and wave action was negligible inside the inlet and 1 to $2 \mathrm{ft}$ outside the inlet.

53. The main observations made from the side-scan sonar survey are summarized as follows:

a. Seaward of the entrance channel and dogleg portion of the north jetty, the bottom is devoid of sand, suggesting that little transport takes place just outside the structure. The sonograph indicates that a 200-ft width of the bottom seaward of the toe of the dogleg is a clean surface of rough coquina limestone (Eigure 29).

b. Side-scan sonar images of the channel showed that the entrance is devoid of sand from the eastern end of the jetties to a point approximately $300 \mathrm{ft}$ to the west. The remainder of the channel is covered with sand. The shoal formation suggests the majority of the sand appears to come from the north.

c. The ripple patterns inside the weir have important implications for the design of the deposition basin. Ripples at the seaward and middle portions of the weir are roughly parallel to the weir (Figure 30). A dramatic change in the angle the ripples make with the weir occurs along a line approximately 200 to $250 \mathrm{ft}$ from the landward end of the weir. At line A, the angle changes to approximately $45 \mathrm{deg}$. This phenomenon indicates that the primary wave and current flow direction changes about $1 / 3$ of the way along the length of the weir to focus the inshore sediment transport toward the southeast corner of the spit. The region west of line $A$ then becomes a potential location for the intake of the sand bypassing plant.

54. Results from the St. Lucie Inlet Study show that side-scan sonar can help determine sand transport paths at the inlet. The information can be valuable in designing sand bypassing systems and has applications for most other coastal projects. 

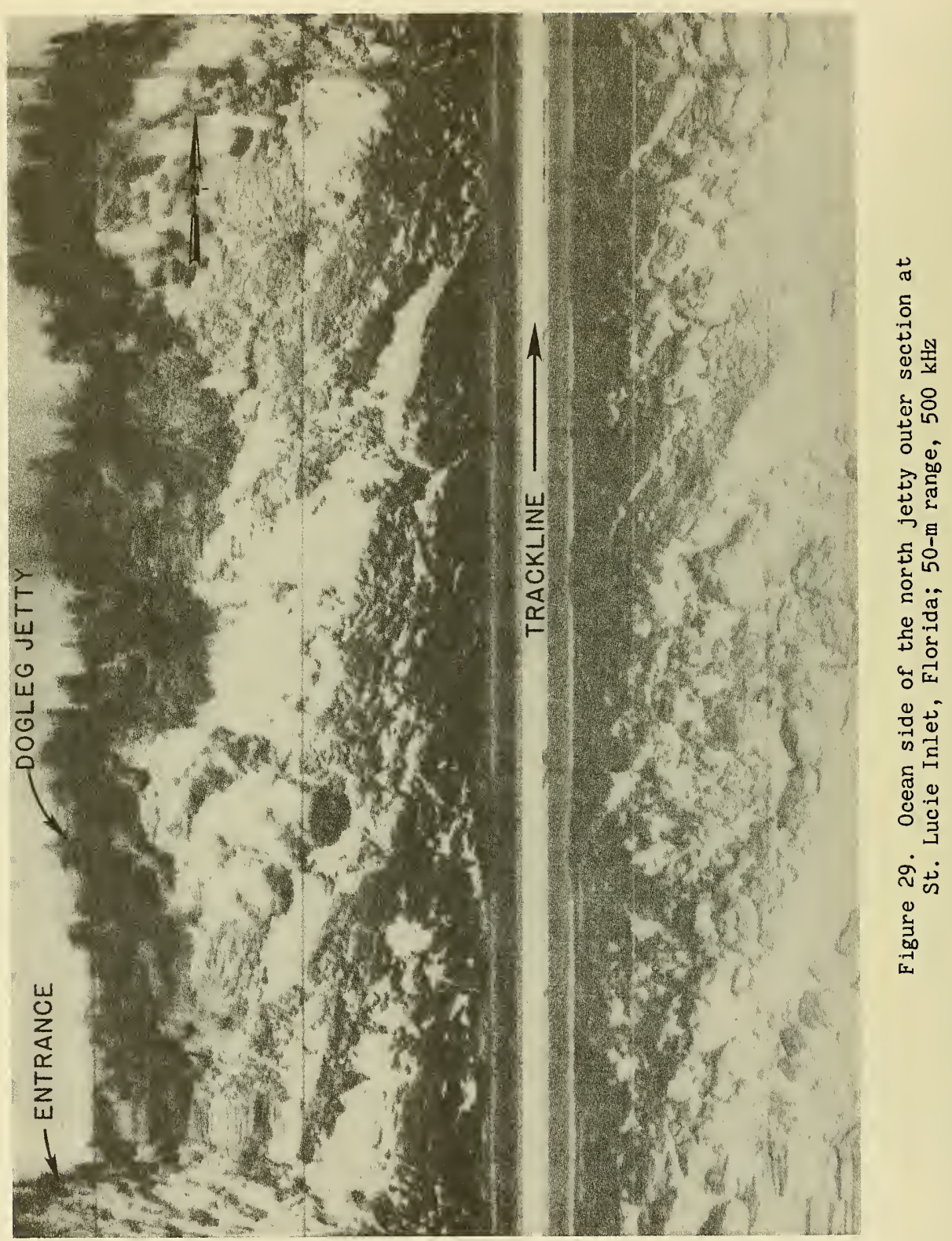


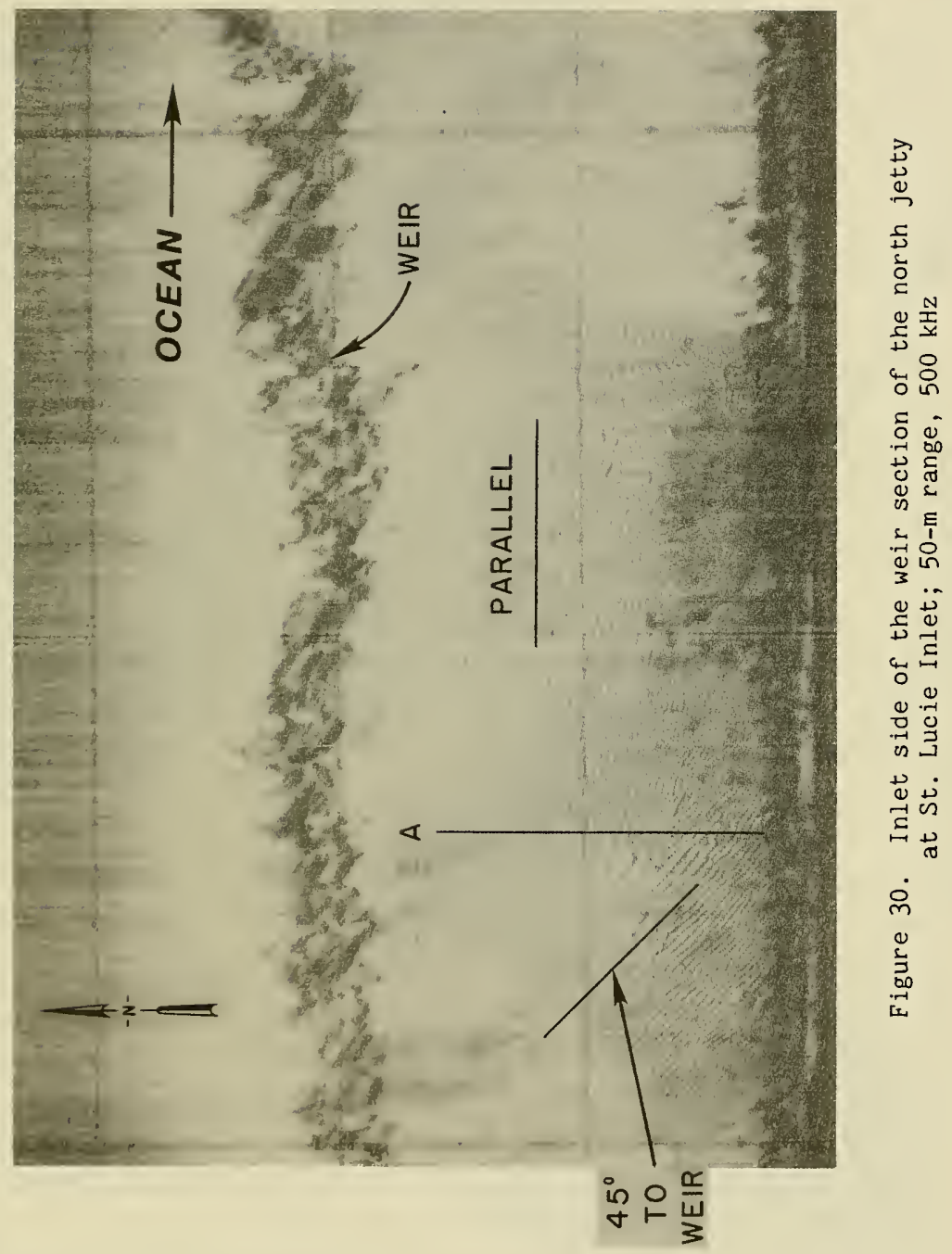


55. As part of the MCCP Program effort at East Pass Inlet, Florida (Figure 31), side-scan sonar inspections of the jetties have been conducted. The purpose of this effort is to document changes in the hydraulics and littoral patterns of the inlet after closure of the weir section of the west jetty in 1985 and to evaluate the stability and effectiveness of the jetties. The latter objective is accomplished primarily through periodic condition surveys in which side-scan sonar is the principal inspection instrument. Side-scan sonar records have shown that a significant scour hole is developing just southwest of the spur jetty. Apparently, tidal currents along the jetties are creating a zone of localized turbulence, resulting in the scour hole.

56. Side-scan surveys were conducted using a Klein model 531-T recorder with a $500-\mathrm{kHz}$ towfish. The survey vessel was a $28-\mathrm{ft}$ outboard powered work boat, which towed the fish at 2-4 knots approximately $6 \mathrm{ft}$ below the surface. Results were improved by attaching the cable at the bow of the vessel to avoid turbulence from the propellers. The majority of the records were obtained using a range of $25 \mathrm{~m}$.

57. The records clearly showed the toe and the face of the structure. Also apparent were individual stones dislodged from the face and an approximately 1-ft-diam steel pipe, probably lost during dredging operations. of particular interest are features that require more interpretation of the record. By examination of the initial bottom return and the shadow zones, it is possible to discern a scour-induced trench along a portion of the east jetty and a deeper scour hole at the southwest tip of the spur jetty.

58. Standard bathymetric surveys around the jetties were also obtained at 200-ft intervals. Comparison of Figures 32a (showing the results of a survey taken in July 1985) and 32b (showing the results of a survey taken in August 1986) illustrates the difficulty of delineating small-scale features at typical bathymetric survey line spacings. Notably, the fathometer survey tracklines miss the center of the scour hole. The principal benefit of a side-scan sonar survey, in this instance, is to identify and locate areas that require closer spacings between bathymetric survey lines. 


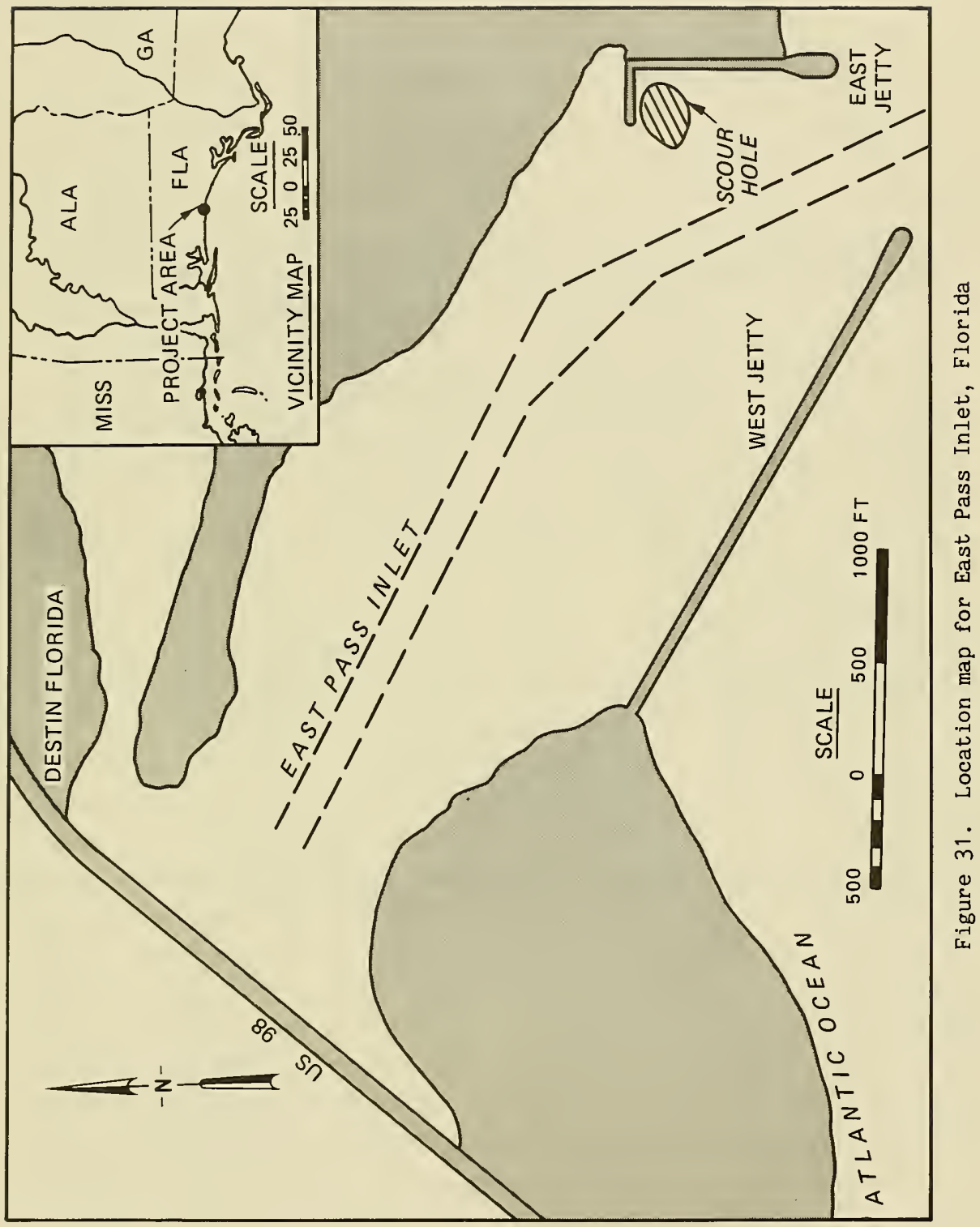



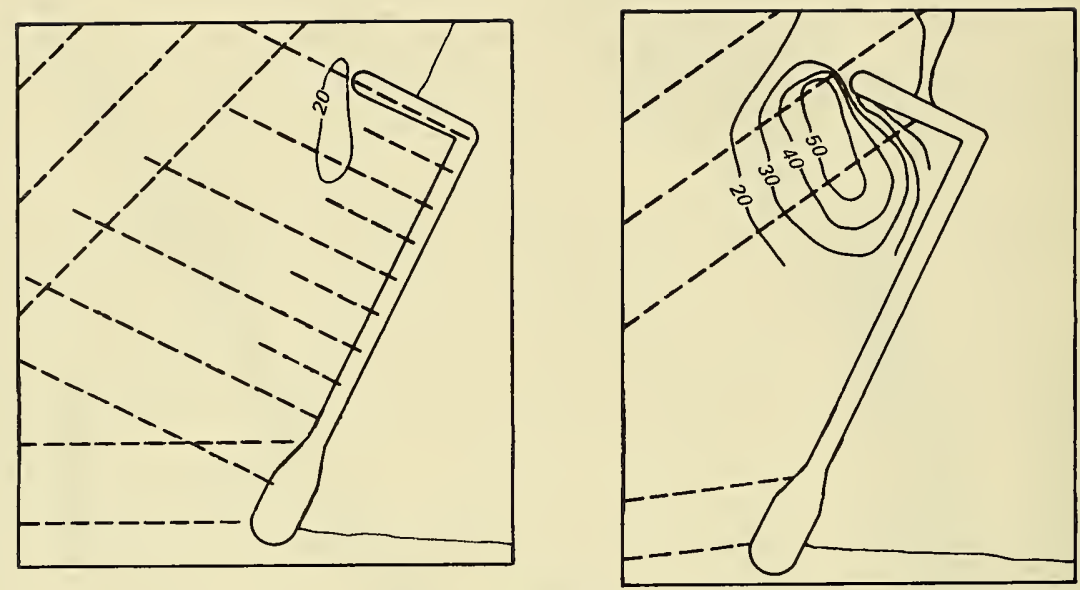

LEGEND

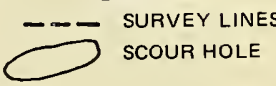

a. July 1985

b. August 1986

Figure 32. Scour hole development at southwest tip of east jetty at East Pass Inlet, Florida 
59. There is a wide variety of other applications where side-scan sonar was used to evaluate coastal related structures described in the literature. While this section is not meant to be a complete list of all coastal structures surveyed with side-scan sonar, it is intended to give the reader an appreciation for the wide range of side-scan sonar applications. This section is divided into three parts: (a) a description of harbor structure inspections, (b) a description of dredged material disposal site inspections, and (c) a discussion of several other applications.

\section{Vertical Wall Harbor Structures}

60. Although inspections of several vertical harbor structures have already been described, there have been several unique applications of sidescan sonar capabilities to inspect these types of structures at other locations. Reduced wave energy and operational requirements often allow or require vertical wall structures in harbors. Because of the orientation of these structures, innovative techniques have been required to obtain useful images. The applications discussed are inspections of concrete caissons in Quebec Harbor and inspection of Navy piers in Norfolk, Virginia.

61. Hydromar, Inc. (1982), a private Canadian Company, used a Klein 500-kHz side-scan sonar with a microprocessor signal processing accessory box to inspect a variety of vertical structures in Quebec Harbor. The absence of waves and the desire to inspect fine details led Hydromar to use a radical departure from conventional inspection techniques. Rather than towing the towfish on a cable, they constructed a steel frame to which the towfish was attached (Figure 33). Limiting towfish movement to only a few centimeters through use of the frame and very slow tow speeds ( 0.5 knots or less), allowed very small features to be identified. The St. Lawrence Seaway's large tidal range at Quebec also allowed visual confirmation of the features seen on the side-scan sonar images. For example, one of the caissons inspected in Quebec was made with tapered forms. The offset between the forms, approximately 2 in. (Figure 34), was visible in the side-scan sonar records as was a ladder and drain hole. Mazel (1984) describes the procedures used in Quebec in detail. 


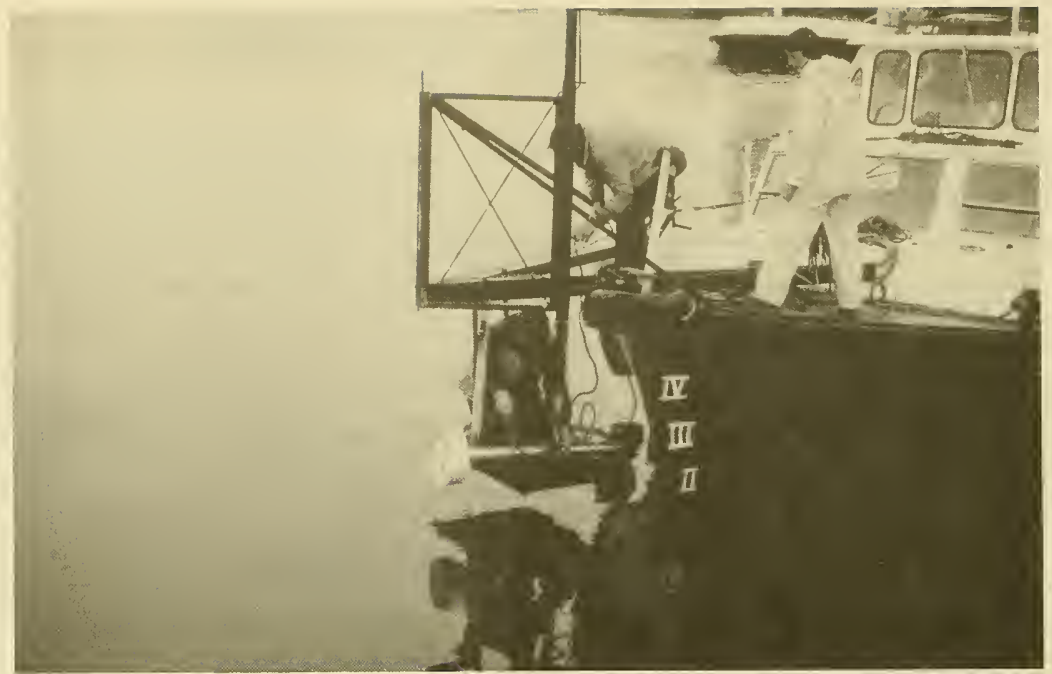

Figure 33. Side-scan sonar being attached to frame on work boat for precision survey of vertical wall structures in

Quebec Harbor, Canada

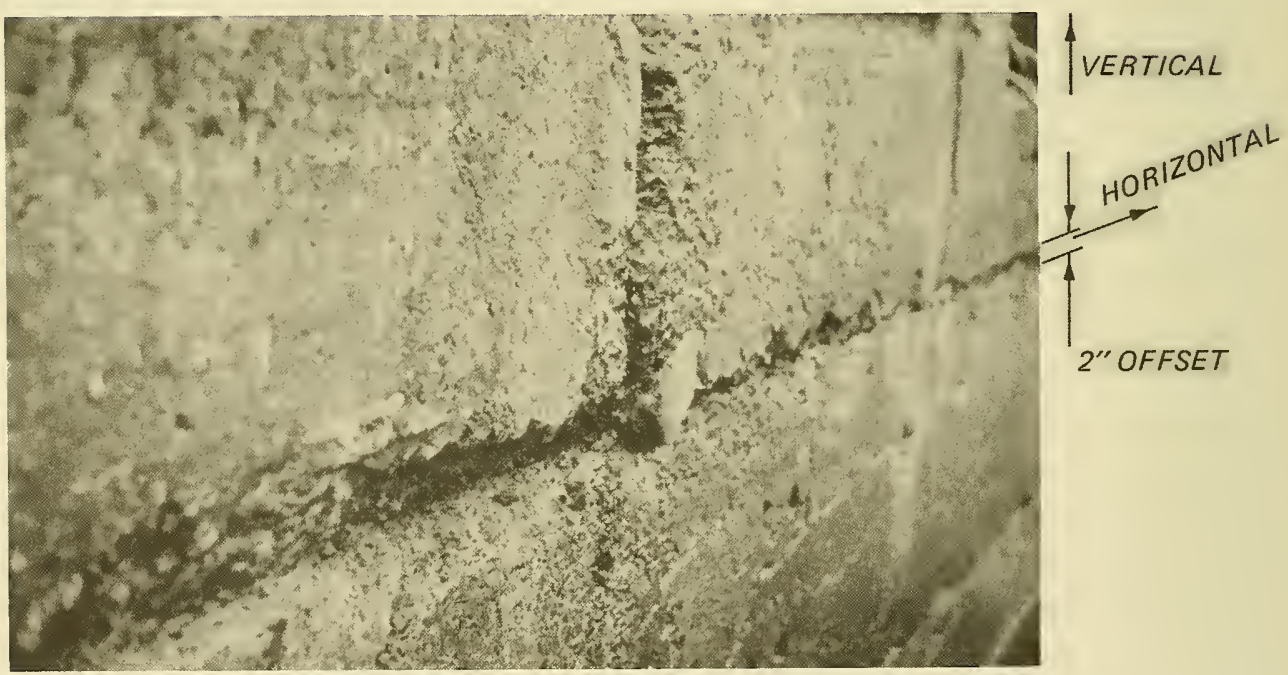

Figure 34. Photograph of offset (approx 2 in.) between concrete caissons in Quebec Harbor, Canada 
62. In an even more radical departure from conventional side-scan sonar inspection techniques, Hydromar rotated the towfish to a vertical position by mounting it on a track attached to their frame. They then used a winch and cable to move the towfish up and down while the ship was stationary. Using this technique, the unit could be made to view a 100- to 150-ft-long section of the wall from top to bottom. Missing vertical members of the wooden fender piles could be seen.

63. The US Navy contracted with Steadfast Marine, Inc. (1982), to perform an inspection of some of the Piers at their facility in Norfolk, Virginia. The quality of the records was improved by rotating the fish, allowing it to look down the pilings from the surface. As a result, the fender pilings stand out in greater detail than the concrete support piles which are some distance behind the wooden fender piles (Figure 35). Also, intact wooden piles, concrete piles, and damaged wooden piles can be seen in Figure 35.

\section{Dredged Material Disposal Sites}

64. As nearshore and offshore open-water disposal of dredged material becomes increasingly popular, the need to monitor these disposal sites will become more important. While these disposal sites are not strictly classified as coastal structures, management of these sites is an important part of a district's dredging program. Side-scan sonar has already proved to be an effective monitoring tool for monitoring disposal sites (US Army Engineer Division, New England (NED) 1985). The side-scan sonar systems used for monitoring disposal sites are the same as or similar to those used for coastal structures. The following paragraphs describe several instances where sidescan sonar has been successfully used to monitor open-water dredged material disposal sites.

65. The Disposal Area Monitoring System (DAMOS) Program has been operating within NED since 1977. DAMOS is a multidisciplinary project covering many aspects of dredged material disposal monitoring and management (NED 1985). Among the many monitoring techniques is side-scan sonar, which has been used at all or most of the nine active disposal sites. Side-scan sonar is used to verify bottom conditions prior to disposal, supplement bathymetric measurements of mound shape, check for large debris in disposal 


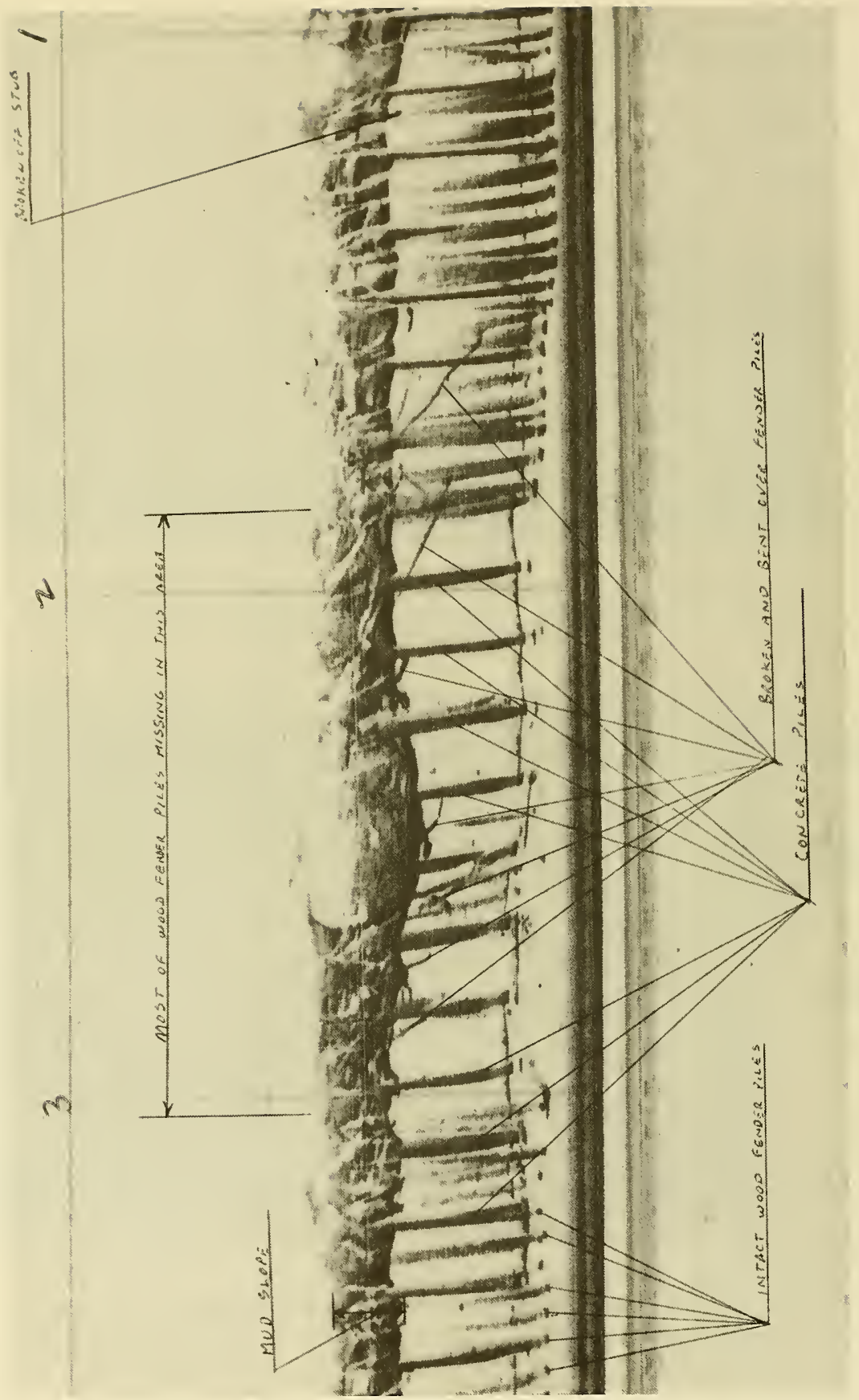

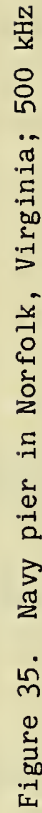


material, verify the extent of the disposal mound, and check mound erosion by the presence of erosive bed features.

66. Two more examples of using side-scan sonar to monitor disposal sites follow. Side-scan sonar was extensively used to monitor the Dam Neck Disposal Site off the Virginia Coast (Hands and Deloach 1984). Figure 36 shows maps produced from side-scan sonar records that illustrate the initial mound boundaries and how they changed through time ( $\mathrm{Clausner} \mathrm{1987).} \mathrm{Changes}$ in the Dam Neck Disposal Site are shown in the predisposal map (36a) and the postdisposal map (36b) produced from side-scan sonar records. The large, low backscatter area in the center of the postdisposal map represents the footprint of the disposal mound. Smaller, low backscatter areas scattered farther afield represent deposits of the finer-grained disposal material. During the Duwamish Waterway Capping Demonstration Project, side-scan sonar was used to provide an estimate of the extent of the sand cap placed over contaminated, fine-grained dredged material (Truitt 1986).

\section{Other Applications}

67. Side-scan sonar has been used for a variety of other coastal engineering related applications. One of the first was to inspect construction of artificial islands for oil exploration in the Arctic (Patterson, Shak, and Czerniak 1982). Concrete mats used for bank protection along the Mississippi River have been inspected with side-scan sonar. The oil industry regularly uses it to inspect conditions and verify location of pipelines. Side-scan sonar has also been proposed as an inspection tool for the Ocean Thermal Energy Conversion plant cold-water intake pipes (Mazel 1984). 


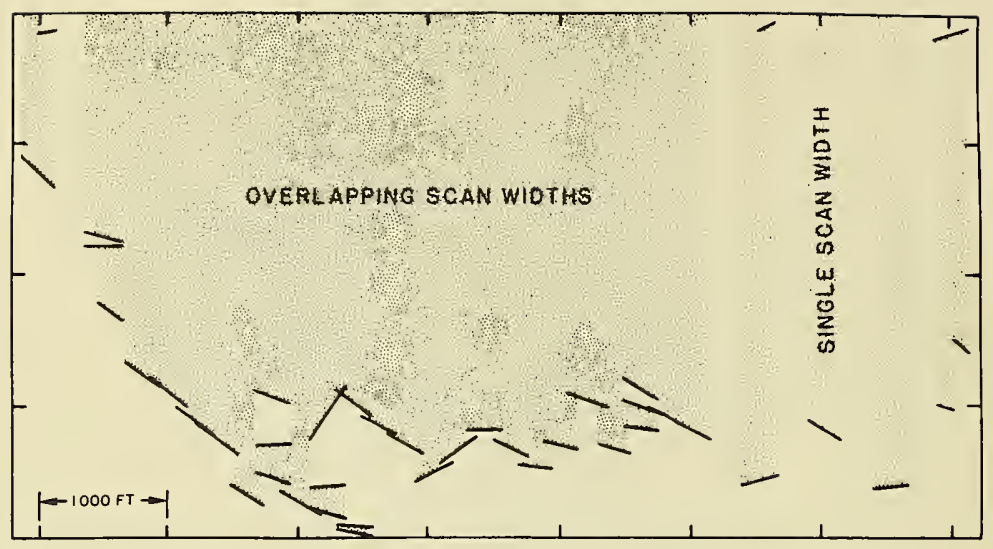

HIGH BACKSCATTER

a. predisposal

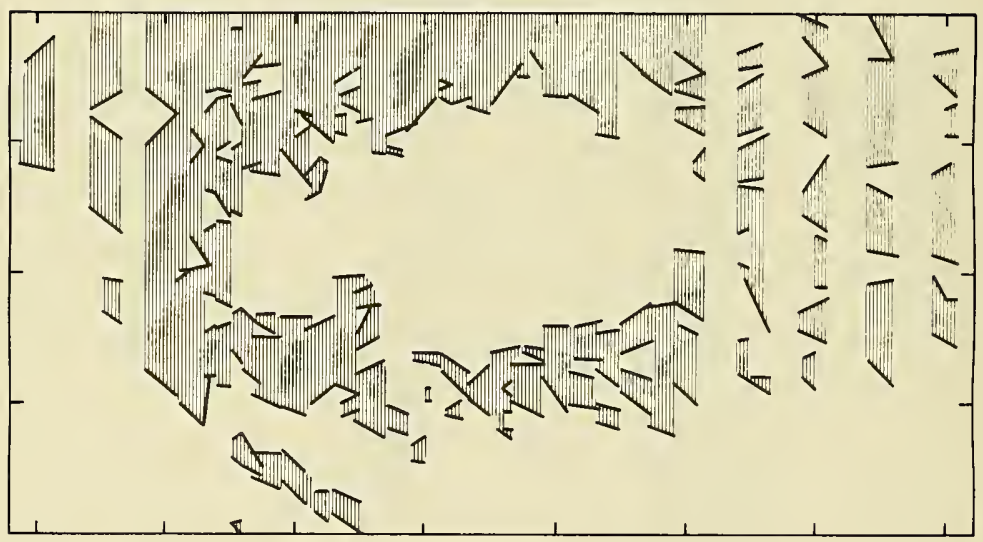

[IIIIIII] HIGH BACKSCATTER

LOW BACKSCATTER

b. postdisposal

Figure 36. Maps of the Dam Neck Disposal Site produced from side-scan sonar records 
68. Side-scan sonar is a potentially useful tool for the reconnaissance and inspection of coastal structures. As noted earlier, there are still equipment and physical limitations on present systems which prohibit quantitative data collection such as structure slope, condition of individual armor units, and percentage of armor units displaced. Side-Scan sonar use is applicable mainly in monitoring programs to qualitative assessments of gross changes. Other types of acoustic imaging systems, such as scanning sonars, have the potential to overcome some of these problems. While detailed discussions of these other acoustic imaging systems is beyond the scope of this report, they are briefly described at the end of Part VI. The reader may consult a recent report from the REMR Program (Howell, Kurcharski, and Clausner in press) which discusses them in more detail.

69. The limitations of side-scan sonar have to be taken into account when planning a survey. Probably the most important item to consider is wave and current conditions. Other limitations include the survey vessel and speed of the survey; site limitations; coastal structure type, including armor material nature, size, and condition; expected reflectivity contrast between the structure and the bottom; instrument setting and behavior; position control; and the experience of the operator. These limitations will be discussed briefly to give the engineer or planner an appreciation of their effect on side-scan sonar operations. Kurcharski and Clausner (in preparation) discuss these limitations in detail.

70. Proper planning and execution should revolve around the intent of the survey and the nature of the structure. The maximum value of side-scan sonar is often realized after some experimentation and imaginative tailoring for the particular location and structure. The clarity of the record and its usefulness are very sensitive to the operating techniques mentioned above which affect the vessel, the site, the instrument and the operator. The following discussions are based on the premise of using a $500-\mathrm{kHz}$ system for coastal structure evaluation. Figures 37 and 38 demonstrate the increased resolution of a $500-\mathrm{kHz}$ system over a $100 \mathrm{kHz}$ system in calm conditions. The greater resolution obtained with the $500-\mathrm{kHz}$ towfish is evident in comparing features A, B, C (Figure 37), and the overall finer detail evident in the $500-\mathrm{kHz}$ portion in Figure 38. In cases of a more severe wave climate, for 


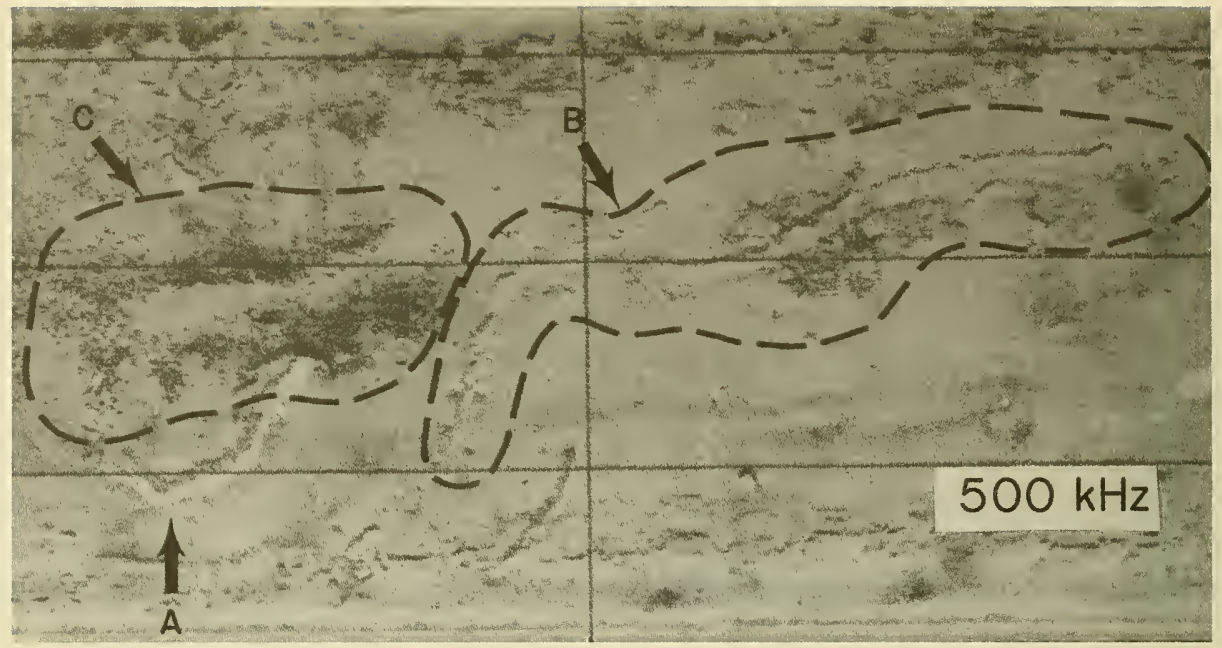

a. 500-kHz towfish

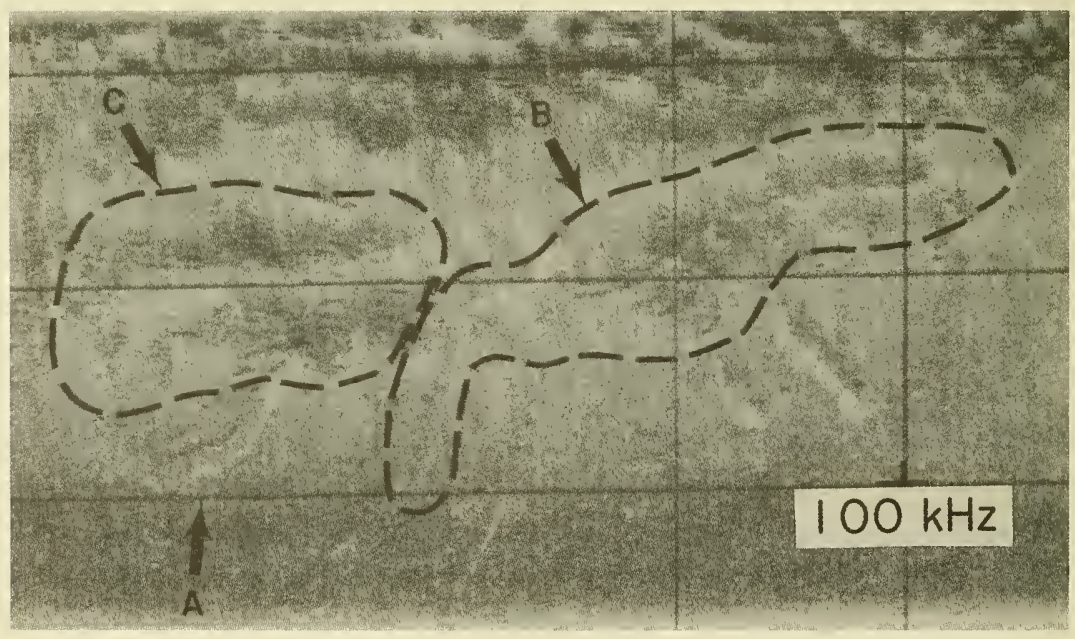

b. 100-kHz towfish

Figure 37. Identical bottom features in Cleveland Harbor, Ohio; range $50 \mathrm{~m}$ 


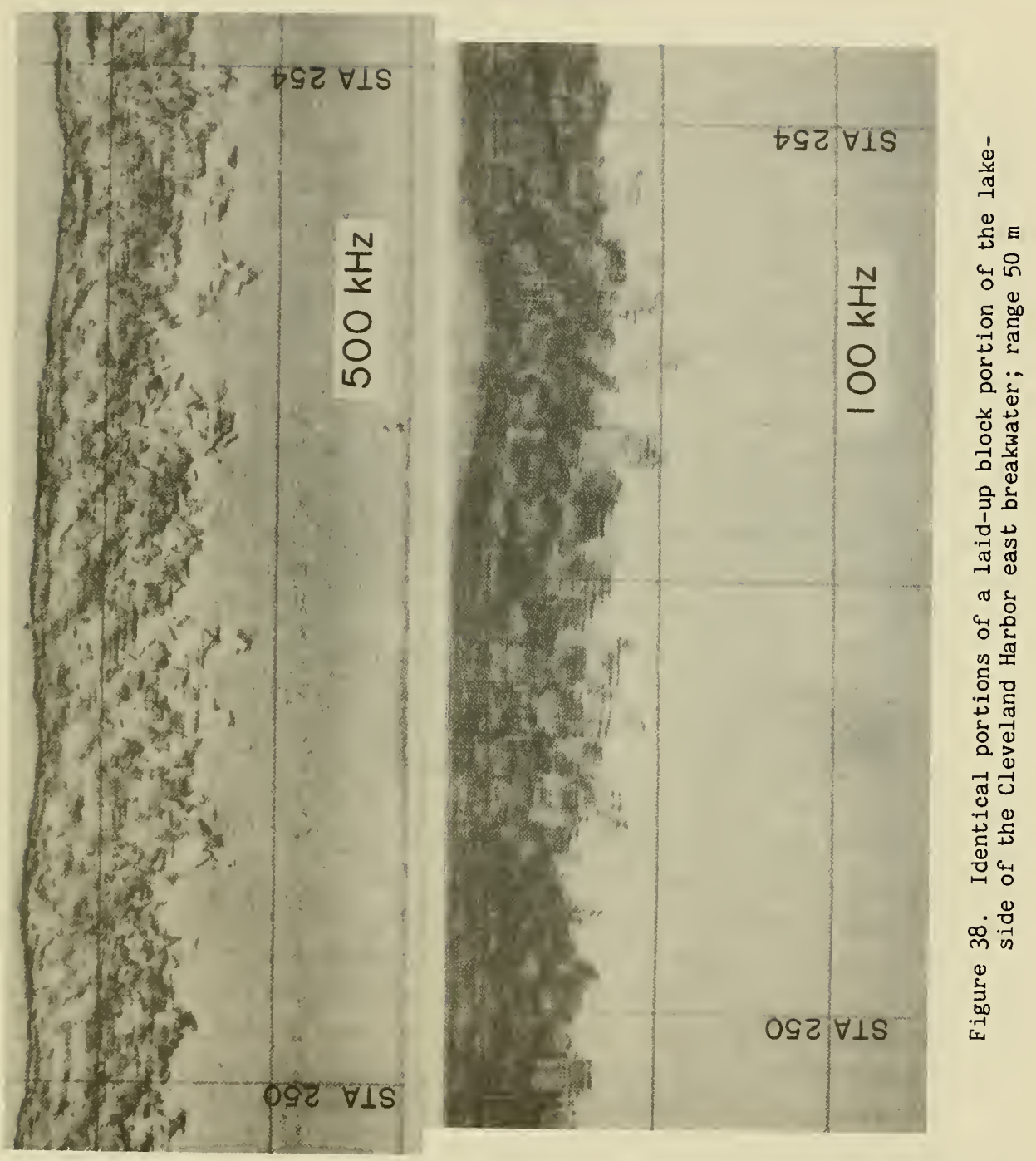


example at Crescent City, California, the $500-\mathrm{kHz}$ system may not provide any resolution advantage, and clarity may be lost due to record smearing.

\section{Vessel Requirements}

71. The vessel to be used in a side-scan sonar survey needs to have power, and stability. Covered deck space capable of protecting the recorder is recommended for most operations, though an open deck can be used when conditions are calm. Ship motion is transmitted to the towfish through the cable. If the motion is of sufficient magnitude or speed, the resulting image on the recorder will be degraded. The size of the vessel in relation to the wave climate is therefore important; i.e., a smaller boat can be used in mild waves, while a larger boat is needed in larger waves. The effects of large waves may force the use of the lower resolution $100-\mathrm{kHz}$ system, as was done at Crescent City, California.

72. Optimum speeds for normal operations is felt by the authors to be between 2 and 4 knots. Faster speeds can be used for general reconnaissance or may be required under certain operating conditions. It is difficult to go much slower than 1.0 knot and still maintain a stable, straight course.

\section{Site Limitations}

73. As stated earlier, the most severe site limitations are wave climate and current conditions. While a larger boat can offset the wave conditions to some degree, once the waves get over several feet high it is nearly impossible to get a quality image in shallow water $(<100 \mathrm{ft}$ ) due to the short cable length which effectively transmits vessel motion to the towfish. Quality surveys of coastal structures are usually performed in waves of $2 \mathrm{ft}$ or less, while nearly calm conditions are preferred. Consequently, the period for successful surveys is limited to seasons of low wave energy, i.e. the summer months. It is prudent, then, to allow a wide weather window, if possible, when planning a side-scan sonar survey.

74. Strong currents can also present side-scan sonar survey problems. The major problem occurs when the current is perpendicular to the path of the survey vessel. At low survey speeds, the towfish will tend to orient itself with the direction of a strong current rather than the survey vessel path. To 
avoid this problem, it is best to run the survey into the current which may require adjusting the time of the survey to take advantage of the optimum current direction. If the survey must be run perpendicular to a strong current, it may be necessary to use a rigid mount (e.g. a pipe clamped to the rail) to negate the current effects.

75. Lack of contrast or too much contrast between the target of interest and the surrounding bottom can be potential problems in side-scan sonar surveys. It may be difficult to clearly define the toe of a stone breakwater if it is situated on a rough bedrock base. In such cases, it may be necessary to make runs with different towfish elevations and positions to highlight the change in slope between the bottom and the structure. The opposite problem can occur with a structure that is a very strong reflector of acoustic energy, such as a sheet-pile wall. If the gain on the recorder is turned down so that a clear image of the wall is obtained, bottom features near the structure may not be visible. In this case, it may be necessary to make runs with different gain settings to view both the wall and the bottom.

76. Other site limitations can also make it difficult to maintain the constant speed and towfish elevation required for good results. Presence of other vessels, both commercial and recreational, can make it difficult to keep the vessel on track. Proper planning in the time of the survey can reduce these problems. Irregular bottom topography and floating debris can also create potentially hazardous situations for the towfish.

\section{Operator Experience}

77. An experienced operator is needed to obtain quality records. Recent advances in digital electronics technology have made some side-scan sonar units produced since 1985 easier to tune for a clear record. However, an understanding of the principles involved, instrument capabilities, and experience greatly increases the probability of producing quality images.

78. Experience is also a critical factor in interpreting the image. Recent construction drawings along with a knowledge of the history of the structure are a great help in interpreting the significance of anomalies in the image. Persons familiar with the area and the structure should be consulted. Local Corps personnel, marina operators, local fishermen, and divers, to name a few, may also provide information that can aid interpreting 
the records. Finally, there is no substitute for visual confirmation of a questionable image. Unexplained features, especially those suggesting an inconsistency in the structure, should be checked by divers or a Remotely Operated Vehicle (ROV) if possible. A few direct observations can be used to help understand a number of miles of records by providing information on key questionable features on the side-scan sonar records. Good position control during the side-scan sonar survey is required to allow the diver or ROV operator to return to the location of the questionable image.

\section{Structure Type}

79. The type of structure to be surveyed will also influence the quality of the record and success of the survey. Structure slope, cover unit size, pattern of placement, and relief of the units will all affect the detail which can be interpreted from the record. Steep-sloped zones on the structure face can shadow other portions of the structure. Slope changes and berms should be easy to identify. The larger size and more regularly shaped armor stones (e.g. rectangular blocks) and armor units (e.g. dolosse) are readily identifiable in most cases. Regular patterned placement plans (e.g. laid-up blocks) give a less confused image than randomly placed units (e.g. typical rubble-mound construction). An armor cover made up of high relief small units will result in a patterned image which is more abstract. 
80. CERC experience has shown that varying the operating variables (e.g. vessel speed, trackline, etc.) and control settings of the side-scan sonar assists in exploring the different details of the structure. This technique allows a more informed interpretation of the surveyed structure. Consequently, the purpose of the survey and the structural details of interest will dictate the procedures used. The authors view the potential purposes of a side-scan sonar survey to include reconnaissance, inspection, and qualitative monitoring. The majority of the following discussion is oriented toward sloping, rough-faced coastal structures and provides some general guidelines. Specific cases may involve changes to those recommendations. Some recently developed acoustic imaging alternative tools which have the potential to overcome some of the limitations of side-scan sonar are presented at the end of the monitoring section. A short discussion on inspecting vertical wall structures concludes this portion of the report.

\section{$\underline{\text { Reconnaissance }}$}

81. Side-scan sonar is best known as a reconnaissance tool. Possible applications to coastal structures are numerous and include locating channel debris, mapping bottom materials, locating lost objects or old structures, and identifying major inconsistencies in the underwater portion of a coastal structure. Larger range scales (50 $\mathrm{m}$ or greater) and higher speeds ( 4 to 6 knots) are possible since fine detail is not required. Runs will generally be made parallel to the structure and some distance seaward of the toe. The approximate position of the boat should be noted on the record. Location of the towfish relative to the boat should also be noted. Positioning could be done without electronic survey control if survey stations on the structure can be observed from the water. In this case the approximate station and estimated distance offshore from the structure can be noted on the record.

\section{Inspection}

82. Use of side-scan sonar as an inspection tool for coastal structures will often require some experimentation with the operating parameters. 
Varying boat speed, location relative to the structure, approach angle, towfish elevation, etc., along with paper speed, range, and gain can all be used to enhance the image or add a new perspective to the structure. The total picture is often arrived at by piecing together observations from several different runs.

83. Inspection requires finer control of the operating parameters than does reconnaissance and is usually done at slow speeds (2 to 4 knots) in ranges of 25 to $50 \mathrm{~m}$. Electronic positioning is strongly recommended, although stations at 100-ft spacing along a structure can be used to determine location with less accuracy. Runs will often be made parallel to the structure, and at least two passes should be made. Runs seaward of the toe with the fish close to the bottom should provide good definition of the toe and berms (Figure 39). By paralleling the structure near the water's edge with the towfish near the surface, it should be possible to look down the structure slope (Figure 39) to observe slope irregularities.

\section{Monitoring}

84. As a monitoring tool, side-scan sonar is far more limited because it cannot be practically used to measure change. Accurate control and duplication of the moving towfish position through space and time are very difficult to accomplish. Slight variations in the towfish location and speed can translate into obvious changes in object perspective and shadow length and shape between different runs. Recently developed acoustic imaging tools aided by microprocessors have the potential to remove some of the side-scan sonar limitations allowing "mapping" of the targets (briefly discussed at the end of this section).

85. Qualitative monitoring is possible and practical, particularly for documenting changes to the structure toe and if the armor cover units are large and distinctive. The changes to structure toe line and objects on the bottom can be identified between surveys. Major changes in the slope relief may also be identified between surveys. However, direct overlaying of the images is not practical. The monitoring value of side-scan sonar is only realized if all operation parameters (i.e. boat speed, towfish depth, position, paper speed, range, etc.) are duplicated as closely as possible between surveys. Short-range microwave positioning should be used and readings taken 


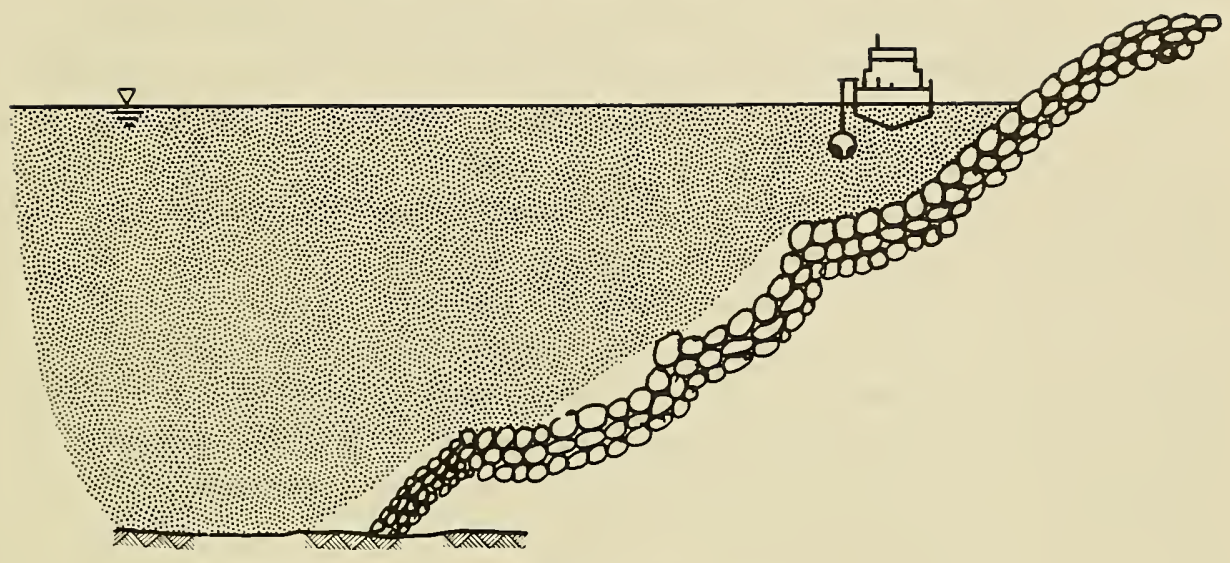

a. Near structure, shallow towfish

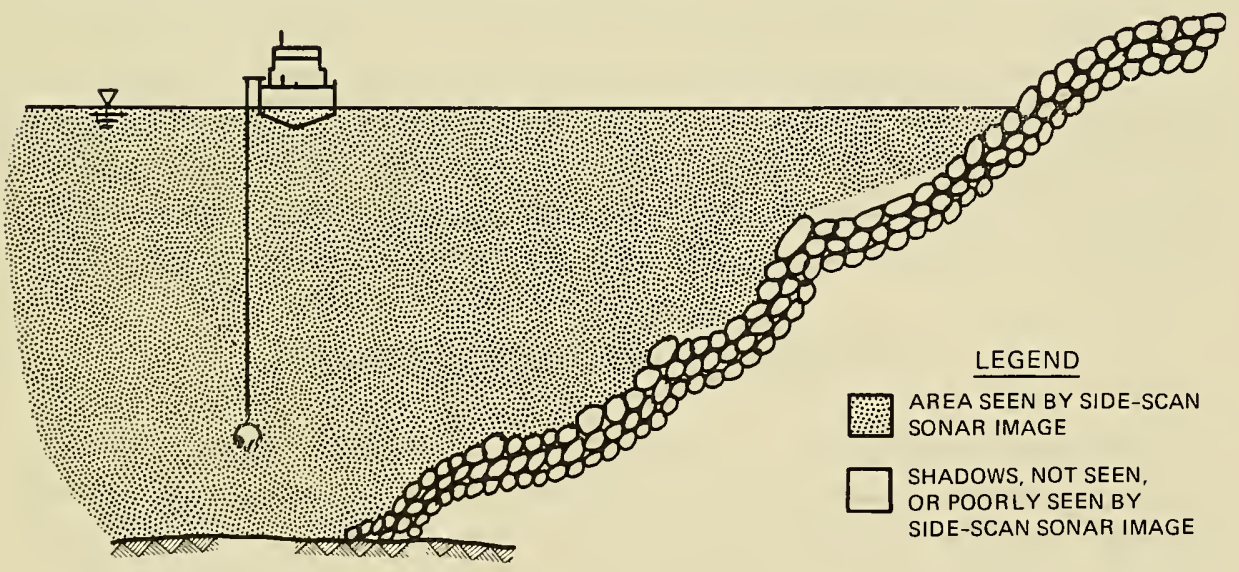

b. Beyond toe, deep towfish

Figure 39. Example of two side-scan sonar inspection passes 
frequently. The side-scan sonar signal should be recorded on magnetic tape for later playback and possible enlargement of key images.

86. Until a few years ago, the only alternative to side-scan sonar inspection of coastal structures was the use of divers. The rapid expansion of ROV technology can, in low turbidity water, allow the engineer on the surface to directly observe the structures by using a small, tethered submersible with a low light TV camera. In clear water an ROV can operate more efficiently and safely (especially in deep water) than a diver.

87. Other types of acoustic imaging instruments are now also bridging the gap between side-scan sonar and visual observations. Scanning sonars, which use high frequency $(675 \mathrm{kHz}$ to $2 \mathrm{MHZ}$ ) sound waves and a rapidly sweeping head, provide acoustic TV pictures on a cathode ray tube (CRT) with potentially greater detail than side-scan sonar, though with less range (up to $25 \mathrm{~m}$ ). The images are recorded on video cassette recorders (VCR's). They can be used while the vessel is still and placed on stationary bottom resting frames to reduce motion to a minimum. Depending on the orientation of the acoustic head, images can be displayed in several modes, including a profile slope cross section. Further investigations and field tests are needed to define the usefulness of scanning sonars, but they have definite potential.

88. Profiling sonar works like conventional fathometers, with the exception of having a rotating head which allows a cross section of the bottom to be surveyed instead of a single point. However, the instrument appears to be sensitive to vessel motion effects, particularly roll, which would limit its effectiveness in the open ocean (Kucharski and Clausner in preparation).

\section{Techniques for Surveying Vertical Walls}

89. Vertical walls can be viewed using the same basic techniques as those used for inspecting sloping structures. However, vertical walls present problems not found in sloping structures. Vertical walls are often made of steel or concrete which are strong reflectors of acoustic energy often creating "cross talk". Additionally, they often have features that are not easily discernible by horizontally moving towfish.

90. However, the low wave environment where vertical wall structures often are found allows the use of alternative inspection methods. Often vertical walls are constructed in areas of low wave energy, allowing the 
towfish to be mounted on a frame and towed at low speeds, as described by Hydromar, Incorporated (1982), and Mazel (1984). These frames can also allow the fish to be moved vertically to provide better images of vertical features. Finally, vertical structures are often topped by roads, providing the potential to deploy the towfish from a truck-mounted crane. 
91. Side-scan sonar results to date have shown that a variety of structures and bottom features can be successfully imaged with side-scan sonar. These applications are categorized as follows:

a. Providing quality control during and after construction. Sidescan sonar could be used to monitor the extent of construction; to explain cost overruns due to material loss or dredging outside of dredging limits; to document proper construction of each layer, of any terraces or berms, and of the structure toe; and to document uniformity of construction.

b. Providing site reconnaissance to define existing structure and site features. Side-scan sonar could be used to save time and money on structure cross sections, bathymetric surveys, sediment sampling, and underwater inspections by identifying specific areas for quantitative survey (i.e., areas of structural anomalies or deterioration, shoals, channels, bedrock outcrops, disposal mounds, sediment interfaces, etc.). Areas of scour and settling could also be documented using side-scan sonar. Bedforms and features of the bottom sediments can be used to interpret local processes.

c. Locating underwater features. Side-scan sonar could be used to locate navigation hazards prior to dredging and clearing operations; lost vessels prior to salvaging; and relict coastal structures, pipelines, cables, and other items of interest in planning, design, or construction.

d. Monitoring changes to existing structures. Periodic comparison of side-scan sonar records could be made to note failure at the structure toe/bottom interface and major changes in the armor cover layer. In addition, side-scan sonar can be used to document scour around piers and structures and note areas of shoaling in channels.

92. The potential variety of applications is much wider than this general list. Use of side-scan sonar on a particular project may provide the user with detail of the structure and its setting beyond the original survey scope. Other applications include any project where there is a need for rapid qualitative information in support of planning, engineering, construction, or maintenance. 
93. Side-scan sonar has been shown to have value as a tool for evaluating coastal structures. However, it is not an answer to all inspection problems because of several limitations due to environmental conditions and the physics of sound transmission in water. The main limitation is wave effects. Wave motion is transmitted from the survey vessel through the cable to the towfish. Large towfish motions severely reduce sonograph quality. This problem can be mitigated somewhat by increasing vessel size, but for many high energy locations the periods of calmer seas needed to produce good quality images are limited. Another limitation is the resultant geometry of the sidescan sonar transmission pattern which sometimes makes it difficult to get the detail needed to interpret the image in areas where there is air entrained in the water column, strong currents, or poor acoustical contrast characteristics. Several methods to improve sonograph quality, such as slow towspeeds, planning to avoid tidal currents and wave entrained water, etc., are presented in the text.

94. The main advantage of side-scan sonar is the speed at which a lengthy structure can be surveyed at a relatively low cost. One or more passes along a structure during a reconnaissance survey may be used to identify areas with questionable images that need additional site-specific inspection. The records from a side-scan sonar inspection may show a change in slope that requires a conventional cross-section survey or a scour hole developing that requires a hydrographic survey. However, it is very expensive to inspect an entire structure using divers or conventional survey techniques. Side-scan sonar can identify the small percentage of a total structure that needs to be investigated by these expensive methods at a low cost.

95. Additional side-scan sonar surveying of the specific site of interest, varying vessel speed, towfish attitude, approach angles, and recorder settings can help define the structure condition beyond the reconnaissance survey. Detailed quantitative monitoring of coastal structures is presently beyond the capability of side-scan sonar. The difficulties of measuring objects with accuracy from a moving platform now prevents determining slope or percent armor units displaced from a structure. As field technology and electronics improve, determining these types of quantities with some degree of accuracy may be possible in the future, particularly if supplemented 
with other types of acoustic imaging equipment.

96. Knowledge of the capabilities and limitations of side-scan sonar should expand its use within the coastal zone as a tool for inspecting structures. The number of side-scan sonars within Corps of Engineers District offices has increased dramatically within the last 5 years. As planners, engineers, and operations personnel become more aware and confident in the capabilities of the instrument, side-scan sonar should see increasing use as a tool for evaluating many different types of coastal structures. As other technologies evolve, side-scan sonar will become one of several different tools available to more effectively deal with the problems associated with coastal structures. 
Clausner, J. E. 1987. "Acoustic Tools and Techniques for Physical Monitoring of Aquatic Dredged Material Disposal Sites," Environmental Effects of Dredging Technical Note EEDP-01-10, Environmental Laboratory, US Army Engineer Waterways Experiment Station, Vicksburg, MS.

Flemming, B. W. 1976. "Side Scan Sonar: A Practical Guide," International Hydrographic Review, Vol 53, No. 1, pp 65-92.

Flemming, B. W., Klein, M., Denbigh, P. N., and Russell-Cargill, W. G. A. 1982. Recent Developments in Side Scan Sonar Techniques, ABC Press (Pty) Ltd, Cape Town, South Africa.

Gebert, J. A., and Clausner, J. E. 1984. "Photogrammetric Monitoring of Dolos Stability, Manasquan Inlet, New Jersey," Proceedings of the 19th Coastal Engineering Conference, American Society of Civil Engineers, Houston, TX.

Gebert, J. A., and Hemsley, J. M. In preparation. "Results of the Monitoring Program at Manasquan Inlet, New Jersey," CERC Technical Report, US Army Engineer Waterways Experiment Station, Vicksburg, MS.

Hands, E. B., and Deloach, S. R. 1984. "An Offshore Mound Constructed of Dredged Material," Proceedings of the Conference on Dredging and Dredged Material, Dredging ' 84 , American Society of Civil Engineers, Clearwater Beach, FL, pp 1030-1038.

Hydromar Incorporated. 1982. "Development of a Methodology for Inspection of Submerged Portions of Harbor Structures with the Aid of Side Scan Sonar," Final Report for the Canadian Public Works Scientific Authority, October.

Klein Associates, Inc. 1985. Side Scan Sonar Training Manual, Salem, New Hampshire.

Kucharski, W. M. and Clausner, J. C. In preparation. "Underwater Inspection of Coastal Structures Using Commercially Available Sonars," CERC Technical Report, US Army Engineer Waterways Experiment Station, Vicksburg, MS.

Mazel, C. H. 1984. "Inspection of Surfaces by Side-Scan Sonar," Preprints of the ROV '84 Remotely Operated Vehicle Conference of the Marine Technology Society, May 14-17, San Diego, CA.

Morang, A. 1987. "Side-Scan Sonar Inspection of Breakwaters at Calumet and Burns Harbors on Southern Lake Michigan," Miscellaneous Paper CERC-87-20, US Army Engineer Waterways Experiment Station, Vicksburg, MS.

Patterson, D. R., Shak, A. T., and Czerniak, M. T. 1982. "Inspection of Submerged Arctic Structures by Side Scan Sonar, Proceedings of the 14 th Annual Offshore Technology Conference, Houston, TX, May 3-6.

Patterson, D. R., and Pope, J. 1983. "Coastal Applications of Side Scan Sonar," Proceedings of Coastal Structures 183 Conference, American Society of Civil Engineers, Washington, DC, pp 902-910.

Pope, J., and Clark, D. R. 1983. "Monitoring of a Dolosse Armor Cover; Cleveland, Ohio," Proceedings of Coastal Structures ' 83 Conference, American Society of Civil Engineers, Washington, DC, pp 193-207. 
Prins, D. A. 1980. "Data Collection Methods for Sand Inventory-Type Surveys," CETA 80-4, Coastal Engineering Research Center, US Army Engineer Waterways Experiment Station, Vicksburg, MS.

Rowan, D., Pope, J., and Hemsley, J. M. In preparation. "Results of the Monitoring Program at Cleveland Harbor, Ohio," CERC Technical Report, US Army Engineer Waterways Experiment Station, Vicksburg, MS.

Steadfast Marine, Inc. 1982. "Norfolk Pier Survey," Report done for the Chesapeake Division, Naval Facilities Engineering Command, Washington, DC.

Truitt, C. L. 1986. "The Duwamish Waterway Capping Demonstration Project: Engineering Analysis and Results of Physical Monitoring," Technical

Report D-86-2, US Army Engineer Waterways Experiment Station, Vicksburg, MS.

US Army Engineer District, Chicago. 1985. "Reconnaissance Report, Breakwater Rehabilitation, Calumet Harbor, Illinois," Limited Distribution Report, Chicago, IL.

US Army Engineer Division, New England. 1985. "DAMOS Disposal Area Monitoring System - Overview of the Program," Waltham, MA.

Williams, S. J. 1982. "Use of High Resolution Seismic Reflection and SideScan Sonar Equipment for Offshore Surveys," CETA 82-5, Coastal Engineering Research Center, US Army Engineer Waterways Experiment Station, Vicksburg, MS. 





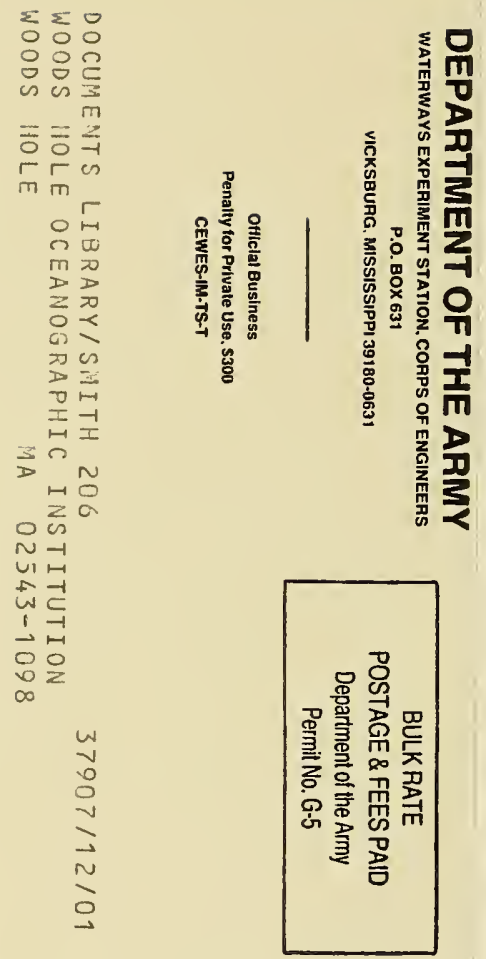

